\title{
DINAMIKA INDUSTRI MANUFAKTUR DAN RESPON TERHADAP SIKLUS BISNIS
}

\author{
Yati Kurniati \\ Yanfitri $^{1}$
}

\begin{abstract}
Abstraksi
The role of the manufacturing industry in the economy has expanded significantly from 19 percent in 1990 to 26 percent in 2009, while its labor absorption only increased from 10 percent to 12.2 percent. The cycle of the manufacturing industry has been in line with the economic growth. This study explores the implications of the firm-level heterogeneity over the business cycle. By using the panel multinomial logit, it shows that firms with less capital and small size have greater probability to exit the industry during the boom/ bust period. Sensitivity of the company to changes in capital is greater during the boom period. Only highly productive firms enter and begin production during recessions. Companies with higher productivity rate also have greater probability to enter the market. In contrast, higher production cost and higher market concentration increase the probability for smaller companies to exit from the industry.
\end{abstract}

JEL Classification: D24, L6, E32

Keywords: Production, Cost, Capital and Total Factor Productivity, Industry Studies Manufacturing, Business Fluctuations/cycles

\footnotetext{
1 Peneliti Ekonomi di Biro Riset Ekonomi (BRE), Direktorat Riset Ekonomi dan Kebijakan Moneter (DKM), Bank Indonesia. Pandangan dalam paper ini merupakan pandangan penulis dan tidak semata-mata merefleksikan pandangan DKM atau Bank Indonesia. E-mail: yati_k@bi.go.id, dan yanfitri@bi.go.id
} 


\section{PENDAHULUAN}

Selama lebih dari dua puluh tahun, peran industri manufaktur dalam perekonomian Indonesia telah meningkat secara substansial, dari 19\% terhadap PDB tahun 1990 menjadi 26\% tahun 2009 (Grafik II. 1). Walaupun selama tahun 1990-2008, sektor industri juga sempat mengalami penurunan pertumbuhan akibat adanya krisis. Di sisi lain, peningkatan lapangan kerja industri manufaktur hanya naik dari $10 \%$ menjadi $12 \%$.

Dinamika sektor industri secara umum bergerak sejalan dengan pertumbuhan ekonomi. Ketika krisis Asia melanda Indonesia tahun 1997/1998, PDB tahun 1998 tumbuh negatif sebesar $13.3 \%$ yang juga diikuti oleh penurunan pertumbuhan sektor manufaktur sebesar $15.4 \%$ (Grafik II.2). Penurunan yang tajam pada output manufaktur tahun 1998 ini juga diikuti oleh penurunan tajam lapangan kerja di sektor manufaktur yaitu sebesar $9 \%$.

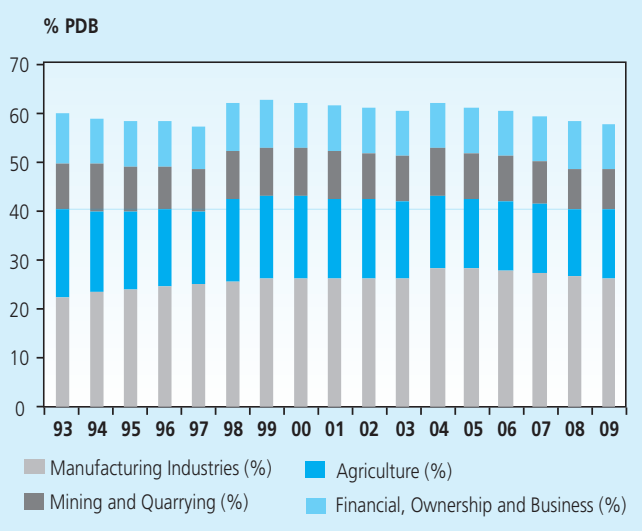

Grafik II.1: Kontribusi Sektor Utama terhadap Perekonomian



Grafik II.2: Pertumbuhan PDB dan Sektor Manufaktur Tahun 1994-2009

Kontribusi sektor manufaktur yang besar terhadap perekonomian menyebabkan siklus perekonomian tidak terlepas dari dinamika sektor manufaktur. Siklus boom dan bust dalam ekonomi sering dikaitkan dengan jumlah perusahaan yang masuk dan keluar dari suatu industri. Selain terhadap perekonomian, dinamika perusahaan juga mempengaruhi penurunan output dan kesempatan kerja sektor manufaktur.

Jumlah perusahaan yang masuk dan keluar juga menjadi berpengaruh bagi fluktuasi makroekonomi karena beberapa alasan. Pertama, dinamika tersebut mungkin disebabkan struktur perekonomian sedang menghadapi guncangan atau perubahan kebijakan. Kedua, jumlah perusahaan yang masuk dan keluar berguna untuk melihat bagaimana implikasi guncangan positif (boom) atau negative (bust). Beberapa penelitian memberikan bukti empiris 
pengaruh siklus bisnis terhadap dinamika industri manufaktur. McQueen dan Thorley (1993) menyatakan kapasitas produksi industri manufaktur di AS akan menurun dan melambat selama masa resesi.

Sebagian besar penelitian menganalisis hubungan antara karakteristik perusahaan manufaktur dengan siklus ekonomi yang berfokus pada negara-negara maju². Belum ada penelitian yang melakukan analisis untuk menunjukkan pola sektor manufaktur dalam beberapa siklus bisnis, khususnya di negara-negara berkembang. Secara eksplisit, penelitian ini bertujuan untuk (i) mengetahui pengaruh perbedaan siklus boom/bust terhadap tingkat keluar/masuk perusahaaan, (ii) mengetahui karakteristik perusahaan yang keluar masuk industri pada periode boom/bust, dan (iii) mengukur pengaruh perubahan karakteristik perusahaan terhadap peluang perusahaan keluar masuk industri pada periode boom/bust.

Penelitian ini ditulis dalam beberapa bagian. Bagian II menjelaskan latar belakang teoritis dan kajian literatur. Bagian III membahas tentang metodologi dan data yang digunakan. Bagian IV menyajikan analisis deskriptif perusahaan yang masuk dan keluar. Bagian $V$ menjelaskan hasil pengolahan data dan Bagian VI menyajikan beberapa kesimpulan.

\section{TEORI}

Perusahaan untuk exist akan berusaha memaksimalkan profitnya. Oleh karena itu, faktor berupa peluang profit dan pertumbuhan sektor tersebut akan menjadi daya tarik untuk memasuki industri tertentu. Di sisi lain, faktor biaya seperti biaya produksi dan biaya lainnya juga menjadi pertimbangan perusahaan yang akan memasuki industri. Disamping itu, karakteristik pasar apakah industri tersebut pasar persaingan sempurna, monopolis, atau diantara keduanya akan mempengaruhi tingkat economic of scale perusahaan dalam memproduksi barang yang pada akhirnya juga mempengaruhi keputusan untuk masuk/keluar dari industri.

Berdasarkan teori perilaku perusahaan, keputusan untuk memasuki industri didasari atas perbandingan antara tambahan keuntungan dan biaya. Berawal dari upaya maksimisasi profit $\pi(Q)=T R(Q)-T C(Q)$, maka terdapat 3 kondisi yang dihadapi oleh perusahaan yakni (i) $P=$ $M R \geq A C$ (Stay or entry industry) dimana $A C=A F C+A V C$, (ii) $P=M R=M C=A V C$ (Shutdown point), (iii) $P=M R \leq A V C$ (Exit industry). Kondisi ini diilustrasikan pada Grafik II.3.

Berdasarkan persamaan tersebut, perusahaan akan memaksimalkan keuntungannya pada saat $P=M R=M C$. Pada poin M (zero profit) perusahaan akan memproduksi barang di tingkat $M R=M C=A C$. Artinya, pada kondisi ini perusahaan tidak memiliki preferensi untuk tetap berada

2 Caballero \& Hammour (1994,2005), Davis \& Haltawanger (1990), dan Lee \& Mukoyama (2007). 
atau keluar dari perusahaan. Sementara pada poin $\mathrm{M}^{\prime}$ atau disebut "shutdown point" dimana perusahaan akan mengalami kerugian pada saat memproduksi output. Pada level ini, atau dapat disebut juga tingkat perusahaan mengambil keputusan untuk keluar dari industri, pendapatan perusahaan hanya cukup untuk menutupi biaya variabel dan kerugian yang diperoleh sebesar biaya tetap. Pada saat harga yang ditetapkan perusahaan berada di bawah AVC, maka perusahaan akan meminimalkan kerugiannya dengan keluar dari industri (Grafik II.3).

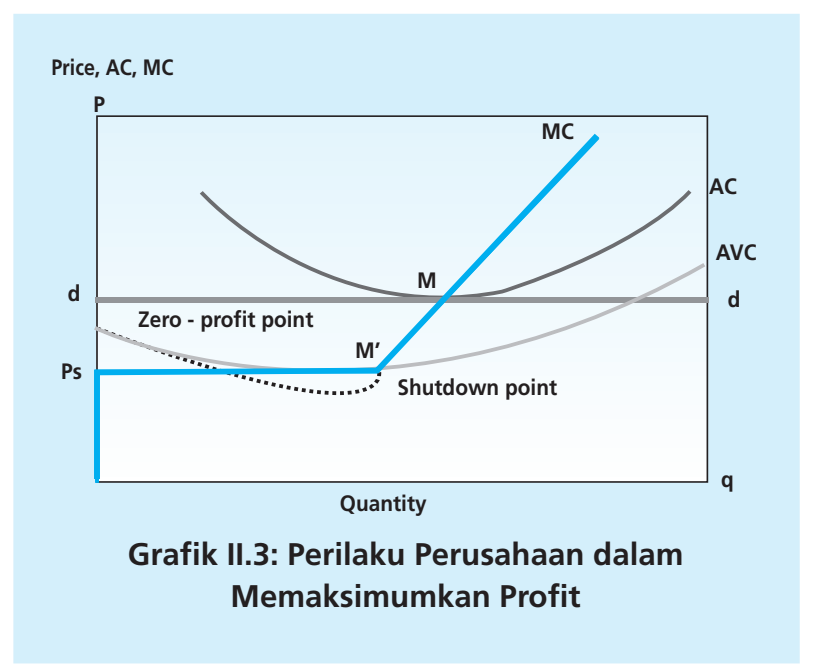

Besaran ATC (Average Total Cost) berbeda-beda tergantung dari karakteristik pasar. Dalam pasar persaingan sempurna, tidak ada hambatan untuk memasuki pasar dan tidak ada perusahaan yang memiliki kekuatan untuk mengendalikan harga pada level tertentu. Industri, dengan karakteristik pasar persaingan sempurna, akan mencapai ATC pada tingkat output yang lebih rendah dibandingkan dengan pasar tidak sempurna. Perusahaan yang memproduksi barang di bawah ATC akan menghasilkan biaya yang akan bertambah lebih cepat dari pertambahan output. Sementara dalam pasar persaingan tidak sempurna kurva ATC relatif datar, sehingga level zero-profit (ATC=MC) dapat dicapai dengan produksi output yang lebih tinggi dari pada pasar persaingan sempurna. Konsekuensi dari karakteristik ini perusahaan kecil akan sulit memasuki pasar.

Selain faktor ATC, faktor bariers to entry juga mempengaruhi keputusan perusahaan untuk masuk atau keluar dari perusahaan. Di dalam pasar persaingan sempurna, hambatan ini tidak ada, akan tetapi untuk pasar tidak sempurna, hambatan berupa biaya iklan, undangundang, dll. Hambatan ini menyebabkan biaya untuk memasuki pasar bertambah.

Berdasarkan hal tersebut, dapat diketahui bahwa perusahaan yang bertahan dalam pasar adalah perusahaan yang memiliki pendapatan minimal setara dengan ATC, sementara 
perusahaan yang tidak dapat menghasilkan pendapatan untuk menutupi level ATC akan keluar dari industri.

Berdasarkan penjelasan di atas, perusahaan akan bertindak rasional, dimana perusahaan akan berproduksi pada tingkat keuntungan yang maksimal. Fungsi sebuah perusahaan dapat dituliskan sebagai berikut. Untuk setiap periode $t$, perusahaan $i$ diasumsikan akan memproduksi jumlah barang yang optimum $q^{*}$ it dengan harga $p_{t}$ dalam fungsi keuntungan sbb:

$$
\pi_{i t}\left(X_{i t}, Z_{t}\right)=p_{t} q_{i t}^{*}-c_{i t}\left(X_{i t}, Z_{t} \mid q_{i t}^{*}\right)
$$

dimana $c_{i t}$ (.) adalah biaya produksi yang dikeluarkan perusahaan untuk memproduksi barang sebanyak, $q^{*}{ }_{i t}, X_{i t}$ vektor yang mewakili karaktersitik perusahaan, $Z_{t}$ adalah vektor eksogen lainnya yang mempengaruhi keuntungan perusahaan.

Perusahaan akan tetap berproduksi apabila penerimaan yang diperoleh dari lebih besar atau sama dengan biaya produksi yang harus dikeluarkan. Sementara apabila penerimaan lebih kecil dari biaya produksi, maka perusahaan akan berhenti berproduksi.

$$
Y_{i t}=\left\{\begin{array}{lll}
1 & \text { if } & \pi_{i t}\left(X_{i t}, Z_{t}\right) \geq 0 \\
0 & \text { if } & \pi_{i t}\left(X_{i t}, Z_{t}\right)<0
\end{array}\right.
$$

Jika terdapat perusahaan membutuhkan biaya masuk (entry cost) saat akan mulai beroperasi, maka fungsi profit perusahaan menjadi :

$$
\tilde{\pi}_{i t}\left(X_{i t}, Z_{t}\right)=p_{t} q_{i t}^{*}-c_{i t}\left(X_{i t}, Z_{t} \mid q_{i t}^{*}\right)-\eta\left(1-Y_{i t-1}\right)
$$

dimana $\eta$ adalah biaya masuk untuk mulai berproduksi.

Persamaan di atas merupakan persamaan pada satu titik waktu, sementara persamaan untuk multi periode dapat dituliskan sebagai berikut :

$$
\Pi_{i t}\left(X_{t}, Z_{i t}\right)=E_{t}\left(\sum_{s=t}^{\infty} \delta^{s-t}\left[\tilde{\pi} . Y_{i s}\right]\right)
$$

Apabila tingkat produksi periode saat ini mempengaruhi biaya produksi pada periode selanjutnya $\left(\frac{\partial c_{i t}(.)}{\partial q_{i t-1}^{*}} \neq 0\right)$, maka keputusan berproduksi sebuah perusahaan merupakan permasalahan dinamis yang dapat dituliskan dalam persamaan sbb :

$$
V_{i t}(\cdot)=\max _{\left\{q_{i t}\right\}}\left(\pi_{i t} \cdot\left[q_{i t}^{*}>0\right]+\delta E_{t}\left[V_{i t+1}(\cdot) \mid q_{i t}^{*}\right]\right)
$$


Sebuah perusahaan akan memilih untuk berproduksi pada periode $t$ apabila nilai dari produksi tersebut lebih besar daripada nilai untuk tidak berproduksi :

$$
\begin{aligned}
& V_{i t}\left(q_{i t}^{*}>0\right)>V_{i t}\left(q_{i t}^{*}=0\right) \\
& \tilde{\pi}_{i t}+\delta E_{t}\left[V_{i t+1}(\cdot) \mid q_{i t}^{*}>0\right]>\delta E_{t}\left[V_{i t+1}(\cdot) \mid q_{i t}^{*}=0\right] \\
& p_{t} q_{i t}^{*}+\delta E_{t}\left[V_{i t+1}(\cdot) \mid q_{i t}^{*}>0\right]-\delta E_{t}\left[V_{i t+1}(\cdot) \mid q_{i t}^{*}=0\right]>c_{i t}+\eta .\left(1-Y_{i t-1}\right)
\end{aligned}
$$

Di dalam model multi periode, biaya untuk masuk ke dalam industri ditangkap dalam hubungan antara aktivitas ekspor dalam 2 tahun yang berurutan.

Di samping teori tentang intertemporal produksi, terkait dengan tingkat masuk/keluar perusahaan dari industrinya, terdapat beberapa teori baru yang mendukung konsep tersebut. Joseph Schumpeter (1942) menyatakan bahwa dinamika perusahaan merupakan proses 'creative destruction'yang selanjutnya dianggap sebagai penyebab utama fluktuasi ekonomi. Schumpter menyatakan kegiatan produksi dengan proses terbaru dan inovasi produk akan tercipta terus menerus sementara proses/barang lama akan dihancurkan. Proses tersebut berfungsi untuk menjelaskan pertumbuhan dan juga siklus bisnis. Industri dapat memiliki variasi yang berbeda terkait dengan tingkat unit produksi yang menggunakan teknik yang baru atau tingkat dimana unit produksi yang outdated dihancurkan.

Di sisi lain, beberapa pemikiran juga tidak sepakat dengan ide dasar creative destruction. Caballero dan Hammour (1994) menyatakan proses produksi outdated keluar dari industri karena adanya penurunan permintaan yang pada akhirnya menyebabkan berkurangnya penciptaan. Caballero dan Hammour (2005) juga mempertanyakan pandangan bahwa resesi akan meningkatkan realokasi. Mereka mempertanyakan pandangan bahwa perusahaan akan menggantikan setiap pekerjaan yang dihilangkan pada masa kontraksi dengan menciptakan pekerjaan baru selama masa pemulihan (panel (d) Gambar II.1). Seperti digambarkan pada panel (a)-(c) Gambar II.1, restrukturisasi pekerjaan selama masa resesi dapat bernilai positif, nol, atau negatif. Efek ini tergantung pada pergerakan ekonomi kontraksi atau pemulihan.

Terdapat beberapa studi yang mengukur faktor-faktor penyebab tingkat masuk dan keluar di sektor manufaktur. Shapiro (1997) menemukan bahwa hubungan antara tingkat keluar masuk perusahaan berhubungan positif dengan produktivitasnya. Keluar/masuk perusahaan adalah bagian dari proses perubahan di mana sejumlah besar perusahaan baru menggantikan sejumlah besar perusahaan lebih tua. Oleh karena itu, tingginya tingkat masuk perusahaan ini sering dikaitkan dengan tingginya tingkat inovasi dan peningkatan efisiensi. Implikasi dari kenaikan produktivitas manufaktur adalah selaras dengan tingkat masuk/keluar tertinggi yang dialami oleh negara-negara industri manufaktur di (Marcos dan Jaumandreu, 2004). 
(a) Restructuring Increases

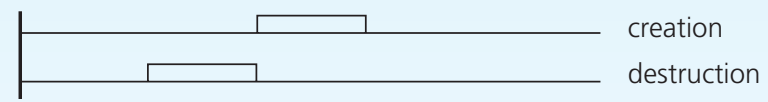

(b) Restructuring is Unchanged

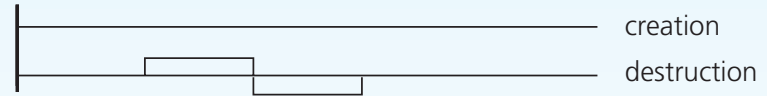

(c) Restructuring Decreases

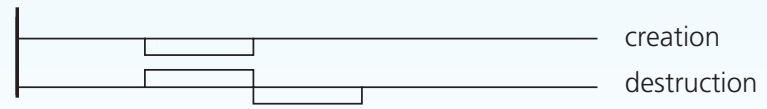

(d) Unemployment Recession

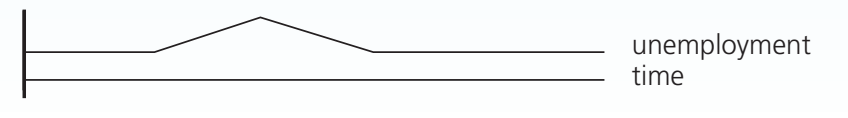

Gambar II.1

Proses Restrukturisasi Industri

Beberapa studi lainnya tentang tentang determinan masuk dan keluar perusahaan industri dikemukakan oleh Audretsch (1995). Audrestch menyimpulkan rasio masuk/keluar perusahaan terkait erat dengan ukuran dan umur perusahaan. Di sisi lain, Marcos dan Jaumandreu (2004) menunjukkan peran penting dari tekanan kompetitif (peningkatan penetrasi pasar impor yang dibuka pada kecepatan yang luar biasa) dan perubahan struktural melalui proses creative destruction yaitu perpindahan perusahaan yang tidak efisien.

Salah satu penelitian yang mencoba menjelaskan perilaku perusahaan di negara maju dilakukan oleh Austin dan Rosenbaum menggunakan data industri manufaktur AS untuk menganalisis tingkat masuk dan keluar berdasarkan sampel yang cukup besar dari 4-digit industri manufaktur AS. Pertumbuhan pasar secara signifikan meningkatkan (mengurangi) tingkat masuk (keluar). Pertumbuhan dan keuntungan (yang diukur dengan menggunakan harga industri-margin biaya kenaikan tarif masuk) juga menjadi faktor penyebab masuknya perusahaan ke dalam industri. Modal sebagai pendekatan pengukuran biaya tetap juga menjadi salah satu hambatan untuk keluar dari industri. Dalam studi ini, Austin dan Rosenbaum juga menambahkan variabel konsentrasi pasar yang turut mempengaruhi tingkat masuk atau keluar.

Studi lain dilakukan untuk industri manufaktur di Cina (Yang, 2004) yang menganalisis perilaku perusahaan yang bertahan, masuk, dan keluar angka berdasarkan ukuran perusahaan, 
produktivitas tenaga kerja, dan indeks efisiensi perusahaan. Peneliti menyimpulkan bahwa proses seleksi kompetitif mulai terbentuk di Cina, dengan perusahaan baru yang masuk berkontribusi secara substansial untuk pertumbuhan dan produktivitas.

Studi di negara berkembang dilakukan oleh OECD (2001) yang menyajikan rangkuman studi empiris terkait produktivitas dan dinamika perusahaan. Produktivitas dapat diukur melalui (1) Perubahan produktivitas pada setiap individu perusahaan (relatif terhadap pasar) (2) proses realokasi yang diperoleh dari proses ekspansi dan kontraksi perusahaan yang ada atau dari proses masuk/keluarnya perusahaan dari industri (dinamika perusahaan). Penelitian-penelitian membagi faktor-faktor yang mempengaruhi dinamika perusahaan menjadi 4 bagian besar, yaitu ukuran perusahaan, umur perusahaan, produktivitas, teknologi dan inovasi, struktur kepemilikan, dan faktor lainnya (minimum efficiency of scales, konsentrasi industri, faktor siklus). Sebagian besar perusahaan dengan skala besar memiliki kecenderungan yang kecil keluar dari industri.

\section{METODOLOGI}

\section{III.1. Teknik Estimasi Panel Logistik}

Penelitian ini menganalisis peluang keberadaan perusahaan dalam suatu industri, dimana setiap perusahaan berpeluang untuk (i) masuk kedalam industri, (ii) tetap dalam industri tersebut, atau (iii) keluar dari industri tersebut. Karena sifat kategori variabel endogen tersebut, maka dalam penelitian ini digunakan model multinomial logit.

Model multinomial logit adalah salah satu bentuk choice mode/ dimana individu (i) memiliki pilihan (j) pada waktu (t), dimana pilihan tersebut lebih dari 2. Tidak seperti probit, model logit tidak terbatas pada data yang terdistribusi normal (Train, 2003). Secara umum, probabilitas individu untuk mengambil suatu pilihan $j$ adalah :

$$
\begin{aligned}
P_{i}(j)=P\left(U_{i j}\right. & \left.=\max U_{i k}\right)=P\left(U_{i j} \geq U_{i k} \text { untuk semua } k \in K\right) \\
& \left.=P\left(\varepsilon_{i k}=\varepsilon_{i j}\right) \leq V_{i j}-V_{i k}\right)
\end{aligned}
$$

dimana,

$$
V_{i j}=\theta^{T} x_{i j}=\beta^{T} Z_{i j}+\gamma_{j}^{T} w
$$

Spesifikasi ini menunjukkan bahwa utilitas $U_{i j}$ merupakan utilitas maksimum diantara seluruh pilihan lain, contohnya jika dibandingkan dengan utilitas $U_{i k}$ untuk $j, k \in K$. Dalam hal ini, $V_{i j}$ menunjukkan pilihan $j$ yang dipilih oleh individu $i$ dari total $K$ pilihan yang tersedia. 
Pada persamaan di atas variabel bebas dibagi menjadi 2, yaitu konstanta ( $w$ ), dan variabel bebas yang bervariasi antar pilihan (zij.)Dengan menggunakan persamaan (II.1) dan asumsi distribusi logit, probabilitas individu $i$ mengambil pilihan $j$ adalah :

$$
P\left(Y_{t}=j\right)=\frac{e^{\theta_{i j}}}{\sum_{j=1}^{J} e^{\theta_{i j}}}=\frac{e^{x_{i j} \beta-w_{i j} \gamma_{j}}}{\sum_{j=1}^{J} e^{x_{i j} \beta+w_{i} \gamma_{j}}}
$$

Dalam multinomial logit harus diidentifikasi pilihan yang menjadi referensi. Apabila pilihan C merupakan pilihan referensi, maka probabilita pilihan A dipilih dari $\mathrm{C}$ adalah :

$$
\frac{P A_{i}}{P C_{i}}=e^{Z A_{i}}
$$

dimana $Z A_{i}=\alpha_{1} X_{1 i}+\alpha_{2} X_{2 i}+\ldots+\alpha_{k} X_{k i}$

Hal yang sama berlaku untuk pilihan $B$ relatif dibandingkan dengan kategori referensi $C$,

$$
\frac{P B_{i}}{P C_{i}}=e^{Z B_{i}}
$$

Dimana $Z B_{i}=\beta_{1} X_{1 i}+\beta_{2} X_{2 i}+\ldots+\beta_{k} X_{k i}$

Dengan demikian, untuk masing-masing pilihan $A, B$ dan $C$, peluang terpilihnya mengikuti persamaan sebagai berikut :

$$
\begin{aligned}
& P C_{i}=\frac{1}{1+e^{Z A}+e^{Z B}} \\
& P A_{i}=\frac{e^{Z A_{i}}}{1+e^{Z A_{i}}+e^{Z B_{i}}} \\
& P B_{i}=\frac{e^{Z B_{i}}}{1+e^{Z A}+e^{Z B_{i}}}
\end{aligned}
$$

Dalam penyelesaian persamaan multinomial logit, dilakukan maksimisasi fungsi likelihood dan ditunjukkan dalam persamaan berikut:

$$
\max _{\beta} L=\prod_{i=1}^{n}\left(P A_{i}\right)^{J A_{i}}\left(P B_{i}\right)^{J B_{i}}\left(1-P A_{i}-P B_{i}\right)^{1-J A_{i}-J B_{i}}
$$


Dari fungsi $L$ tersebut maka interpretasi perubahan probabilitas $A$ berdasarkan perubahan variabel bebas adalah sebagai berikut :

$$
\begin{aligned}
\frac{\partial P A_{i}}{\partial X_{k i}} & =\frac{e^{Z A}}{1+e^{Z A}+e^{Z B}} \alpha_{k}-\frac{e^{Z A}}{\left(1+e^{Z A}+e^{Z A}\right)^{2}}\left(e^{Z A_{i}} \alpha_{k}+e^{Z B_{i}} \beta_{k}\right) \\
& =\frac{e^{Z A_{i}}}{1+e^{Z A}+e^{Z A_{i}}}\left(1-\frac{e^{Z A}}{\left(1+e^{Z A}+e^{Z A}\right)}\right) \alpha_{k}-\frac{e^{Z A_{i}}}{1+e^{Z A}+e^{Z A}} \frac{e^{Z B}}{1+e^{Z A}+e^{Z A}} \beta_{k} \\
& =P A_{i}\left(1-P A_{i}\right) \alpha_{k}-P A_{i} \cdot P B_{i} \cdot \beta_{k}
\end{aligned}
$$

Berdasarkan persamaan tersebut terdapat 2 faktor yang menyebabkan perubahan probabilitas memilih $A$ akibat perubahan variabel bebas $X$ yaitu own effect dan cross effect. Perhitungan probabilitas di atas mewakili seluruh periode observasi yang diestimasi. Dalam panel data, peluang untuk menentukan pilihan $j$ berdasarkan karakteristik $X_{i t}$ memiliki variasi antar individu dan antar waktu sehingga utilitas individu untuk mengambil pilihan $j$ dalam waktu $t$ untuk individu $n$ adalah sebesar :

$$
U_{n j t}=\beta_{n} x_{n j t}+\varepsilon_{n j t}
$$

$\operatorname{dimana} \boldsymbol{\varepsilon}_{n j t}$ memiliki variasi antar individu, waktu, dan alternatif. Spesifikasi fungsi logit yang dimaksimukan untuk persamaan panel adalah sebagai berikut :

$$
L=\prod_{i=1}^{N} \int_{-\infty}^{\infty} \prod_{t=1}^{T} \prod_{j=1}^{J}\left(\frac{\exp \left(X_{i t} \beta_{j}+a_{j}\right)}{\sum_{k=1}^{j} \exp \left(X_{i t} \beta_{k}+a_{k}\right)}\right)^{d_{i j t}} f(a) d a
$$

Dengan mengintegralkan sisi kiri (LHS) dan sisi kanan (RHS), maka kini maksimisasi dilakukan atas integral fungsi $L$. Dalam kasus umum, proses maksimisasi suatu fungsi dilakukan dengan langkah perubahan yang kecil, $h$, untuk keseluruhan interval fungsi. Pendekatan ini dikenal dengan composite quadrature yang mengasumsikan bahwa dalam seluruh interval, fungsi tersebut smooth dan tidak memiliki variasi yang besar (equally spaced points). Pendekatan yang lebih baik untuk maksimisasi fungsi integral $L$ di atas adalah adaptive quadrature mendekati angka integral tersebut dengan nilai tertentu menggunakan metode dengan membuat posterior distribution dari unobserved heterogenity (Haan dan Uhlendorff, 2006). Secara teknis, pendekatan adaptive quadrature ini membuat langkah yang lebih kecil dari h untuk interval dimana fungsi tersebut memiliki fluktuasi yang lebih besar (heterogen).

Analog dengan spesifikasi peluang terpilihnya setiap kejadian sebagaimana ditunjukkan pada persamaan sebelumnya, namun kali ini, peluang setiap individu (cross-section) dapat 
diperoleh. Secara teknis, estimasi panel logistik ini dilakukan dengan perangkat lunak STATA ${ }^{3}$. Terkait dengan pemilihan model fixed dan random effect, dalam STATA sendiri, tidak terdapat perintah untuk multinomial logit dengan fixed effect karena tidak ada bukti statistik yang cukup bahwa fixed effect dapat dikondisikan dengan maksimum likelihood. Estimasi model fixed effect akan menghasilkan estimator yang inkonsisten dan bias (Bernard and Jensen, 2004). Dengan demikian, penelitian ini menggunakan multinomial logit random effect.

\section{III.2. Data, Konseptualisasi dan Pengukuran Variabel}

Mengacu pada teori dan studi empiris sebelumnya, maka model empiris yang diestimasi dalam paper ini diberikan di bawah ini. Tanda plus dan minus pada masing-masing variabel mewakili hipotesa awal yang diajukan, dan berlaku baik pada masa boom maupun bust.

$$
\begin{aligned}
& P(\text { Entry })=f\left(\text { size }^{+}, \text {cr }^{-},\right. \text {modal } \\
&
\end{aligned}
$$

Data yang digunakan adalah data Survey Industri Menengah dan Besar dari tahun 19902007. Adapun tingkat masuk/keluar/bertahan perusahaan dihitung dengan menggunakan definisi sebagai berikut :

- Perusahaan yang entry atau masuk ke dalam industri dikategorikan sebagai perusahaan yang exist pada periode $t$, namun non-exist pada pada periode $t$ - 1 .

- Perusahaan yang exit atau keluar dari industri dikategorikan sebagai perusahaan yang nonexist pada periode $t$, namun exist pada periode $t$ - 1 .

- Perusahaan yang survive/bertahan dalam industri adalah perusahaan yang exist pada setidaknya 3 periode berturut-turut yaitu periode $t-1, t$ dan $t+1$.

Variabel penjelas yang digunakan dalam model empiris dan pemilihan indikatornya adalah sebagai berikut:

1. Total Factor Productivity (TFP) = Perhitungan TFP dengan menggunakan Solow Residual dan fungsi Cobb Douglas. Fungsi Cobb Douglas ditulis sebagai berikut :

$$
Y=A K^{\alpha} L^{1-\alpha}
$$

$\ln Y=\ln A+\alpha \ln K+(1-\alpha) \ln L$

Sehingga TFP (In A) merupakan residual dari kapital dan labor yang dibutuhkan untuk memproduksi output pada tingkat tertentu. Data TFP ini kemudian dihitung berdasarkan 
ISIC 3 digit setiap tahun dengan menggunakan metodologi OLS cross sections. Nilai dan akan bervariasi antar sub industri, tergantung karakteristik industri tersebut, apakah memiliki fungsi produksi increasing return to scale, decreasing return to scale, atau constant return to scale. Perhitungan teknologi dengan menggunakan solow residual ini tidak memperhitungkan dampak peningkatan teknologi yang diakibatkan oleh sektor lain.

2. Concentration Ratio $(\mathrm{CR})=$ tingkat konsentrasi pasar untuk mengidentifikasi apakah industri tertentu merupakan kelompok pasar persaingan sempurna atau monopoli. Nilai concentration ratio berada antara 0 sampai dengan 1, dimana 0 menunjukkan karakteristik pasar persaingan sempurna, sementara 1 menunjukkan pasar monopoli. Adapun CR dihitung dengan menggunakan persamaan sebagai berikut :

\section{$C R=\frac{10 \text { output teratas }}{\text { total output sub industri tertentu }}$}

3. Dummy variabel (boom/bust) menunjukkan siklus bisnis perekonomian ${ }^{4}$. Adapun dummy ini dihitung berdasarkan deviasi pertumbuhan ekonomi satu periode tertentu terhadap rataratanya antar waktu. Periode boom adalah periode pertumbuhan ekonomi yang berada di atas reratanya, sebaliknya dengan periode bust.

Rata-rata yang digunakan sebagai dasar penentuan periode boom/bust, dibagi menjadi 2 bagian, yaitu : periode sebelum krisis (tahun 1990-1996) dengan rata-rata pertumbuhan ekonomi sebesar 7,25\% per tahun, dan periode sesudah krisis (tahun 2000-2006) dengan rata-rata pertumbuhan sebesar 5,10\% per tahun (Grafik II.4 dan II.5).

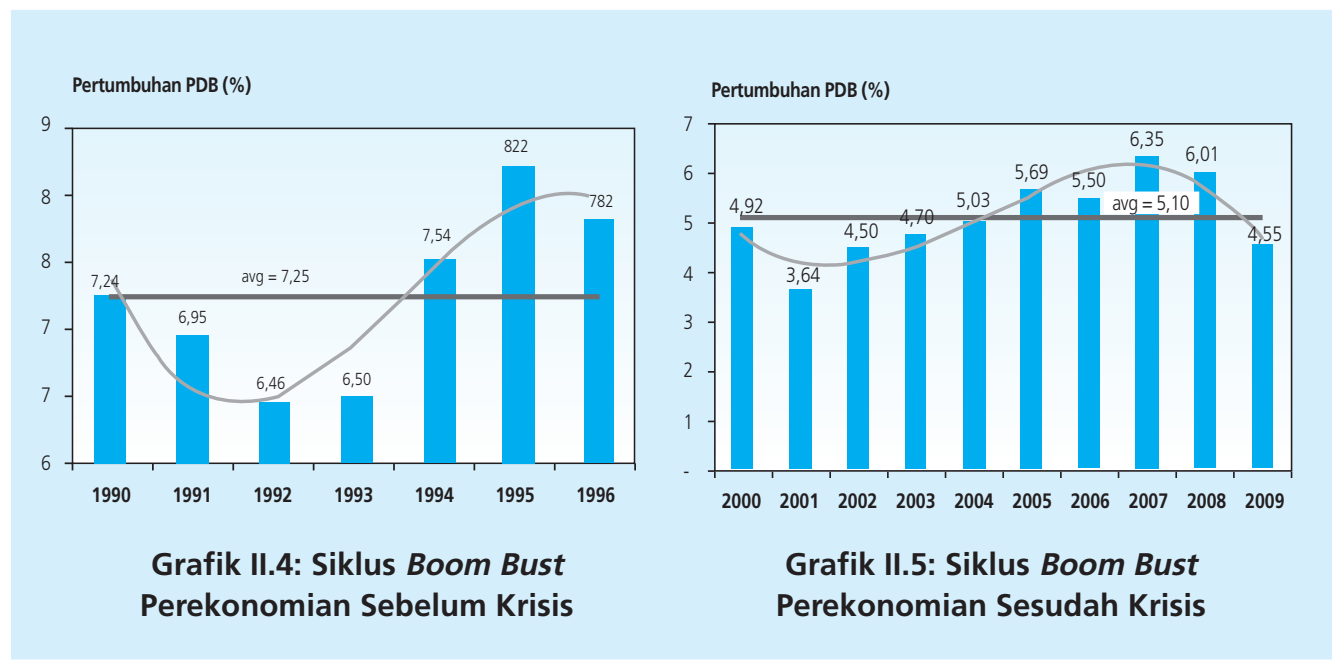

4 Siklus boom bust juga dihitung dengan menggunakan variabel upah riil (lampiran), dan periodisasi boom bust tidak terdapat perbedaan yang signifikan dengan menggunakan PDB. Oleh karen itu, dalam penelitian ini tetap digunakan definisi boom bust dengan menggunakan variabel PDB. 
Berdasarkan hasil perhitungan rerata dan deviasi tersebut, maka dapat ditentukan sbb :

- Periode Boom meliputi tahun 1990, 1994, 1995, 1996, 2005, dan 2006

- Periode Bust meliputi tahun 1991, 1992, 1993, 1997, 1998, 1999, 2000, 2001-2004.

4. Variabel lain yang digunakan adalah jumlah tenaga kerja produksi yang menunjukkan ukuran perusahaan, modal perusahaan dan upah tenaga kerja produksi.

\section{HASIL DAN ANALISIS}

\section{IV.1. Perkembangan Sektor Industri}

Sektor industri merupakan sektor yang signifikan kontribusinya dalam perekonomian. Pada tahun 1967 - 1997, pertumbuhan sektor industri hampir selalu berada di atas pertumbuhan ekonomi. Pertumbuhan ekonomi pada periode tersebut memiliki rata-rata sebesar 6,1\% sementara pertumbuhan sektor industri mencapai 10,3\% per tahun. Pada masa tersebut berbagai kebijakan dilakukan untuk meningkatkan pertumbuhan sektor industri diantaranya subtitusi impor dan orientasi ekspor (Grafik II.6).

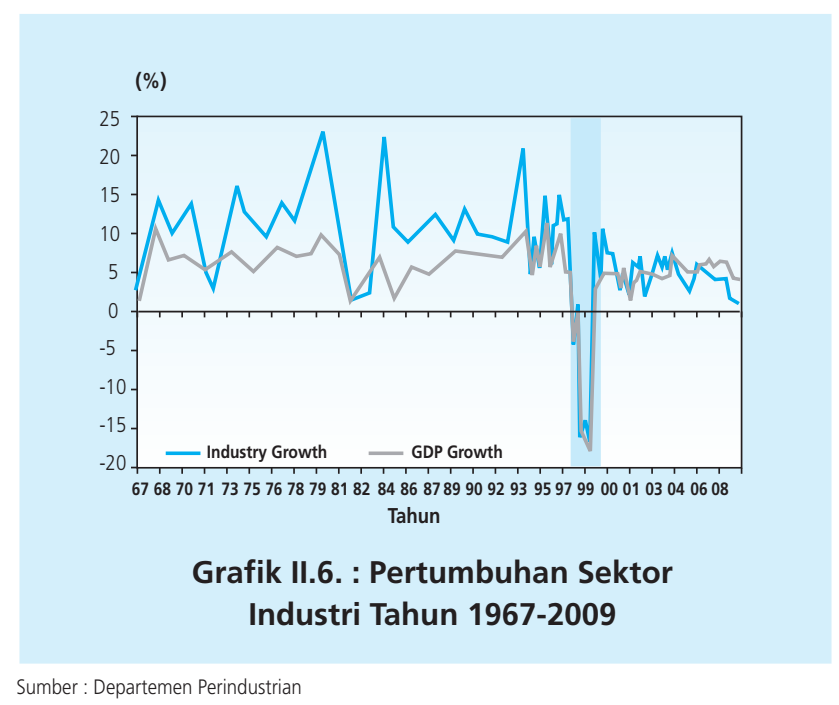

Perubahan besar terjadi pada tahun 1997-2004, pada masa tersebut terjadi krisis dalam perekonomian dan pertumbuhan sektor industri hanya mencapai 3,1\%. Setelah tahun 1997, pertumbuhan sektor industri selalu berada di bawah pertumbuhan ekonomi. Akibat penurunan pertumbuhan tersebut, pemerintah melakukan revitalisasi dan restrukturisasi industri. Apabila dilihat kontribusi sektor industri terhadap perekonomian Indonesia, sampai dengan tahun 2004, rata-rata sektor industri memiliki kontribusi sebesar $26.9 \%$ terhadap perekonomian, dimana $86,5 \%$ kontribusi tersebut berasal dari industri non migas. 


\begin{tabular}{|c|c|c|c|c|c|c|c|}
\hline \multirow{3}{*}{ No } & \multirow{3}{*}{ Manufacturer of } & $\begin{array}{l}\text { II.1 } \\
\text { Istri ter }\end{array}$ & ladap P & erekon & mian & & \\
\hline & & \multicolumn{6}{|c|}{ Growth (\%) } \\
\hline & & 2004 & 2005 & 2006 & 2007 & 2008 & $2009 *$ \\
\hline 1 & Food, Beverages, and Tobacco Products & 1,39 & 2,75 & 7,22 & 5,05 & 2,34 & 3,66 \\
\hline 2 & Textiles, Wearing Apparel; Dressing of Leather & 4,06 & 1,31 & 1,23 & $-3,68$ & $-3,64$ & $-5,15$ \\
\hline 3 & Wood and Products of Wood & $-2,07$ & $-0,92$ & $-0,66$ & $-1,74$ & 3,45 & 2,44 \\
\hline 4 & Paper and its Products; Publishing, Printing & 7,61 & 2,39 & 2,09 & 5,79 & $-1,48$ & 0,61 \\
\hline 5 & $\begin{array}{l}\text { Coke, Refined Petroleum Products, Chemicals; } \\
\text { Rubber and Plastics Products }\end{array}$ & 9,01 & 8,77 & 4,48 & 5,69 & 4,46 & 3,50 \\
\hline 6 & Cement and Other Non-Metallic Mineral Products & 9,53 & 3,81 & 0,53 & 3,40 & $-1,49$ & $-1,50$ \\
\hline 7 & Basic Metals, Fabricated Metal Products & $-2,61$ & $-3,70$ & 4,73 & 1,69 & $-2,05$ & 0,55 \\
\hline 8 & Machinery, Transport, and Equipment & 17,67 & 12,38 & 7,55 & 9,73 & 9,79 & 8,75 \\
\hline \multirow[t]{4}{*}{9} & Others & 12,77 & 2,61 & 3,62 & $-2,82$ & $-0,96$ & 2,82 \\
\hline & Total & 7,51 & 5,86 & 5,27 & 5,15 & 4,05 & 3,97 \\
\hline & & \multicolumn{6}{|c|}{ Share in the Industry (\%) } \\
\hline & & 2004 & 2005 & 2006 & 2007 & 2008 & 2009* \\
\hline 1 & Food, Beverages, and Tobacco Products & 28,10 & 28,18 & 27,95 & 29,79 & 30,40 & 30,91 \\
\hline 2 & Textiles, Wearing Apparel; Dressing of Leather & 13,80 & 12,20 & 11,91 & 10,56 & 9,21 & 8,75 \\
\hline 3 & Wood and Products of Wood & 5,60 & 5,55 & 5,82 & 6,19 & 6,43 & 6,64 \\
\hline 4 & Paper and its Products; Publishing, Printing & 5,30 & 5,41 & 5,24 & 5,12 & 4,56 & 4,51 \\
\hline 5 & $\begin{array}{l}\text { Coke, Refined Petroleum Products, Chemicals; } \\
\text { Rubber and Plastics Products }\end{array}$ & 16,90 & 12,26 & 12,56 & 12,49 & 13,53 & 13,52 \\
\hline 6 & Cement and Other Non-Metallic Mineral Products & 4,20 & 3,89 & 3,80 & 3,70 & 3,53 & 3,48 \\
\hline 7 & Basic Metals, Fabricated Metal Products & 2,90 & 2,88 & 2,69 & 2,58 & 2,57 & 2,45 \\
\hline 8 & Machinery, Transport, and Equipment & 22,50 & 28,72 & 29,09 & 28,70 & 28,97 & 28,95 \\
\hline \multirow[t]{2}{*}{9} & Others & 0,80 & 0,92 & 0,94 & 0,85 & 0,80 & 0,78 \\
\hline & Total & 100,00 & 100,00 & 100,00 & 100,00 & 100,00 & 100,00 \\
\hline
\end{tabular}

Sumber : Departemen Perindustrian

Secara detail kepada sub industri, sub industri alat angkut, mesin, dan peralatannya memiliki peran yang meningkat. Pada tahun 1999, sub industri tersebut hanya memberikan kontribusi sebesar 5,9\% terhadap perekonomian, sementara tahun 2000 meningkat menjadi 20,7\% dan peningkatan tersebut konsisten sampai dengan 2004 yaitu mencapai 26,5\%.

Setelah diberlakukan revitalisasi industri sejak tahun 2004, pertumbuhan positif pada seluruh sub industri. Dalam Tabel II.1 dapat dilihat bahwa industri makanan, barang kayu dan hasil hutan mengalami pertumbuhan positif. Pertumbuhan terbesar dialami oleh sub industri alat angkut, mesin, dan peralatan (12,46\%). Di sisi lain sub industri tersebut juga memiliki kontribusi yang besar terhadap perekonomian yaitu mencapai $28.95 \%$ pada tahun 2009. Akan tetapi penyerapan tenaga kerja sektor ini relatif kecil. Tingkat penyerapan tenaga kerja yang besar adalah sub industri makanan, minuman, dan tembakau.

Tingkat utilisasi kapasitas sub industri juga bervariasi selama tahun 2004-2009. Utilisasi kapasitas terbesar dimiliki oleh sub industri kertas dan barang cetakan. Sementara industri 


\begin{tabular}{|c|c|c|}
\hline \multicolumn{3}{|c|}{$\begin{array}{l}\text { Tabel II.2 Rata-rata } \\
\text { Pertumbuhan Sub industri Tahun 2004-2009 }\end{array}$} \\
\hline $\begin{array}{l}\text { Industri } \\
\text { (dalam ISIC } 2 \text { digit) }\end{array}$ & $\begin{array}{c}\text { Pertumbuhan } \\
(\%)\end{array}$ & $\begin{array}{c}\text { Jumlah Tenaga Kerja } \\
\text { Kumulatif } 5 \text { Tahun (orang) }\end{array}$ \\
\hline 1. Makanan, Minuman dan Tembakau & 4,59 & 514.557 \\
\hline 2. Tekstil, Barang Kulit, dan Alas Kaki & 6,65 & 485.955 \\
\hline 3. Barang Kayu dan Hasil Hutan & 4,91 & 133.119 \\
\hline 4. Kertas dan Barang Cetakan & 7,82 & 42.595 \\
\hline 5. Pupuk, Kimia, dan Barang dari Karet & 10,63 & 143.273 \\
\hline 6. Semen dan Galian Non-Logam & 10,13 & 5.918 \\
\hline 7. Logam Dasar, Besi dan Baja & 3,94 & 341.388 \\
\hline 8. Alat Angkut, Mesin dan Peralata & 12,46 & 96.510 \\
\hline 9. Barang Lainnya & 10,2 & 887.853 \\
\hline Total & 8,56 & 2.635 .690 \\
\hline
\end{tabular}

\begin{tabular}{|c|c|c|c|c|c|c|}
\hline \multirow{3}{*}{ Cabang Industri } & $\begin{array}{l}\text { | II.3 } \\
\text { Pereko }\end{array}$ & nomian & Tahun & $2004-20$ & & \\
\hline & \multicolumn{6}{|c|}{ Persen (\%) } \\
\hline & 2004 & 2005 & 2006 & 2007 & 2008 & $2009 *$ \\
\hline Makanan, Minuman dan Tembakau & 28,1 & 28,18 & 27,95 & 29,79 & 30,40 & 30,91 \\
\hline Tekstil, Barang Kulit, dan Alas Kaki & 3,8 & 12,20 & 11,91 & 10,56 & 9,21 & 8,75 \\
\hline Barang Kayu dan Hasil Hutan & 5,6 & 5,55 & 5,82 & 6,19 & 6,43 & 6,64 \\
\hline Kertas dan Barang Cetakan & 5,3 & 5,41 & 5,24 & 5,12 & 4,56 & 4,51 \\
\hline Pupuk, Kimia, \& Barang dari Karet & 16,9 & 12,26 & 12,56 & 12,49 & 13,53 & 13,52 \\
\hline Semen \& Barang Galian Non-Logam & 4,2 & 3,80 & 3,80 & 3,70 & 3,53 & 3,48 \\
\hline Logam Dasar, Besi dan Baja & 2,9 & 2,88 & 2,69 & 2,58 & 2,57 & 2,45 \\
\hline Alat Angkut, Mesin dan Peralata & 22,5 & 28,72 & 29,09 & 28,70 & 28,97 & 28,95 \\
\hline Barang Lainnya & 0,8 & 0,92 & 0,94 & 0,94 & 0,80 & 0,78 \\
\hline Total Industri & 100,00 & 100,00 & 100,00 & 100,00 & 100,00 & 100,00 \\
\hline
\end{tabular}

yang mengalami pertumbuhan utilisasi kapasitas yang tinggi adalah industri perkapalan akibat pemberdayaan industri dalam negeri dan regulasi pemerintah yang mendorong sub industri tersebut melakukan ekspor.

Di sisi sebaliknya penurunan utilisasi kapasitas dialami oleh industri pupuk, kimia, dan barang dari karet terutama pada tahun 2008. Penurunan utilisasi kapasitas tersebut terjadi karena kurangnya pasokan gas bumi sebagai bahan baku dan energi.

Dari sisi ekspor Industri pengolahan Kelapa/Kelapa Sawit, Industri Besi Baja, Industri Mesinmesin dan Otomotif, Industri Tekstil, Industri Pengolahan Karet, dan Industri Elektronika merupakan penyumbang terbesar terhadap nilai ekspor non migas. Umumnya industri manufaktur non migas selama empat tahun pertama mempunyai kecenderungan nilai ekspor yang meningkat, kecuali pada tahun 2009 karena menurunnya permintaan dari luar negeri akibat krisis global. 


\begin{tabular}{|c|c|c|c|c|c|c|c|}
\hline \multicolumn{8}{|c|}{$\begin{array}{c}\text { Tabel II.4 } \\
\text { Tingkat Utilisasi Kapasitas Sub Industri Tahun 2004-2009 }\end{array}$} \\
\hline No & Kelompok & 2004 & 2005 & 2006 & 2007 & 2008 & 2009* \\
\hline 1 & Industri Baja & 53,1 & 56,3 & 57,8 & 60,5 & 59,8 & 56,62 \\
\hline 2 & Industri Non Logam & 63,62 & 65,68 & 62,8 & 65,1 & 63,6 & 54,89 \\
\hline 3 & Industri Logam Hilir & 56,05 & 59,9 & 62,7 & 61,1 & 61,9 & 60,74 \\
\hline 4 & Industri Mesin & 63,4 & 67,1 & 67,7 & 69,7 & 71,3 & 66,76 \\
\hline 5 & Industri TPT & 67,7 & 69,4 & 70 & 75,81 & 68,2 & 70,52 \\
\hline 6 & Industri Aneka & 58,5 & 59,6 & 58,75 & 58,97 & 58,53 & 59,41 \\
\hline 7 & Industri Perkapalan & 50 & 50 & 60 & 70 & 80 & 50,00 \\
\hline 8 & Industri Kendaraan Bermotor Roda Dua & 79,4 & 78,4 & 67,5 & 71,5 & 73,8 & 74,27 \\
\hline 9 & Industri Kendaraan Bermotor Roda Empat & 43,8 & 59,1 & 32,9 & 45,7 & 57,04 & 47,69 \\
\hline 10 & Industri Elektronika & 67 & 68,3 & 70 & 70 & 73 & 68,21 \\
\hline 11 & Industri Telematika & 65 & 65 & 68,1 & 68,2 & 68,4 & 65,88 \\
\hline 12 & Industri Makanan, Minuman dan Tembakau & 55,2 & 56,1 & 55,8 & 57,6 & $58,32 *$ & 55,69 \\
\hline 13 & Industri Barang Kayu dan Hasil Hutan & 64,8 & 64,7 & 63,4 & 63,5 & $62,98^{*}$ & 64,42 \\
\hline 14 & Industri Kertas dan Barang Cetakan & 79,6 & 83,2 & 88,5 & 88,8 & $92,37^{*}$ & 84,06 \\
\hline 15 & Industri Pupuk, Kimia dan Barang Dari Karet & 71,1 & 72,3 & 67,1 & 67,2 & $65,56^{*}$ & 71,07 \\
\hline \multirow[t]{2}{*}{16} & Industri Semen \& Bahan Galian Non Logam & 61,1 & 62,5 & 64,4 & 71,7 & $75,40 *$ & 61,60 \\
\hline & Rata - Rata Industri & 63,1 & 65,1 & 63,8 & 66,9 & $67,93^{*}$ & 64,20 \\
\hline
\end{tabular}

Sementara industri pengolahan Industri Besi Baja, Industri Elektronika, Industri Kimia Dasar, Industri Tekstil dan Industri Makanan dan Minuman merupakan penyumbang terbesar terhadap nilai impor non migas. Umumnya industri manufaktur non migas selama lima tahun terakhir mempunyai kecenderungan nilai impor yang meningkat.

\begin{tabular}{|c|c|c|c|c|c|c|c|}
\hline & Ekspor Sub & $\begin{array}{r}\text { Tak } \\
\text { lustri } \mathrm{Ma}\end{array}$ & $\begin{array}{l}\text { el II.5 } \\
\text { lufaktur }\end{array}$ & lahun 200 & 7-2009 & & \\
\hline No & Uraian & 2004 & 2005 & 2006 & 2007 & 2008 & $2009 *$ \\
\hline 1 & Pengolahan Kelapa/Kelapa Sawit & $4,840.30$ & $5,419.19$ & $6,407.27$ & $10,476.83$ & $16,168.07$ & $13,249.46$ \\
\hline 2 & Besi Baja, Mesin - Mesin dan Otomotif & $4,581.84$ & $5,949.69$ & $7,712.68$ & $9,606.92$ & $11,814.98$ & $10,720.08$ \\
\hline 3 & Tekstil & $7,626.15$ & $8,584.85$ & $9,422.75$ & $9,790.09$ & $10,116.35$ & $9,947.69$ \\
\hline 4 & Pengolahan Karet & $2,954.10$ & $3,545.82$ & $5,465.16$ & $6,179.87$ & $7,579.66$ & $6,947.25$ \\
\hline 5 & Elektronika & $7,142.50$ & $7,853.03$ & $7,200.19$ & $6,359.73$ & $6,806.70$ & $6,656.97$ \\
\hline 6 & Pengolahan Tembaga, Timah dll. & $2,165.08$ & $3,133.52$ & $4,133.97$ & $6,156.04$ & $5,660.67$ & $5,713.40$ \\
\hline 7 & Pulp dan Kertas & $2,817.61$ & $3,257.48$ & $3,983.27$ & $4,440.09$ & $5,219.62$ & $4,859.62$ \\
\hline 8 & Pengolahan Kayu & $4,461.62$ & $4,476.25$ & $4,757.59$ & $4,485.14$ & $4,206.12$ & $4,372.99$ \\
\hline 9 & Kimia Dasar & $2,640.07$ & $2,750.22$ & $3,521.44$ & $4,492.50$ & $3,738.35$ & $4,019.17$ \\
\hline 10 & Makanan dan Minuman & $1,440.12$ & $1,647.92$ & $1,866.00$ & $2,374.83$ & $3,104.85$ & $2,736.36$ \\
\hline 11 & Alat-alat Listrik & $1,232.73$ & $1,456.03$ & $1,770.93$ & $2,148.88$ & $2,390.24$ & $2,259.58$ \\
\hline 12 & Kulit, Barang kulit dan Sepatu/Alas Kaki & $1,553.04$ & $1,683.69$ & $1,913.17$ & $2,006.60$ & $2,260.46$ & $2,148.35$ \\
\hline Tota & 12 Besar Industri & $43,455.17$ & $49,757.71$ & $58,154.42$ & $68,517.92$ & $79,066.08$ & $73,702.89$ \\
\hline Tota & Industri & $48,660.11$ & $55,566.99$ & $64,990.33$ & $76,429.60$ & $88,351.70$ & $82,314.00$ \\
\hline Non & Migas & $55,939.28$ & $66,428.36$ & $79,589.15$ & $92,012.32$ & $107,894.15$ & $100,163.05$ \\
\hline Mig & & $15,645.33$ & $19,231.60$ & $21,209.48$ & $22,088.57$ & $29,126.27$ & $25,970.29$ \\
\hline
\end{tabular}




\begin{tabular}{|c|c|c|c|c|c|c|c|}
\hline \multicolumn{8}{|c|}{$\begin{array}{c}\text { Tabel II.6 } \\
\text { Impor Sub Industri Manufaktur Tahun 2004-2009 }\end{array}$} \\
\hline No & Uraian & 2004 & 2005 & 2006 & 2007 & 2008 & $2009 *$ \\
\hline 1 & Besi Baja, Mesin mesin dan Otomotif & 13.620 .20 & $17,531.04$ & $17,031.41$ & $20,539.04$ & $39,978.13$ & $33,689.13$ \\
\hline 2 & Elektronika & $2,048.47$ & $2,413.48$ & $2,488.31$ & $4,035.98$ & $13,444.71$ & $10,445.41$ \\
\hline 3 & Kimia Dasar & $5,690.64$ & $5,935.32$ & $6,315.39$ & $7,115.75$ & $10,716.70$ & $9,641.02$ \\
\hline 4 & Tekstil & $1,036.36$ & $1,026.87$ & $1,085.68$ & $1,192.00$ & $3,901.78$ & $3,023.93$ \\
\hline 5 & Makanan dan Minuman & $1,390.67$ & $1,914.52$ & $2,178.23$ & $3,616.14$ & $3,157.97$ & $3,440.27$ \\
\hline 6 & Pulp dan Kertas & $1,299.76$ & $1,298.95$ & $1,392.04$ & $1,692.60$ & $2,518.49$ & $2,279.81$ \\
\hline 7 & Alat - alat Listrik & 724.42 & 877.79 & 852.98 & $1,118.31$ & $2,470.79$ & $2,036.17$ \\
\hline 8 & Pupuk & 431.99 & 518.87 & 624.65 & 761.78 & $2,337.64$ & $1,843.82$ \\
\hline 9 & Barang - barang Kimia lainnya & $1,078.06$ & $1,167.23$ & $1,170.03$ & $1,293.82$ & $1,845.64$ & $1,671.44$ \\
\hline \multicolumn{2}{|c|}{ Total 9 Besar Industri } & $27,320.57$ & $32,684.07$ & $33,138.71$ & $41,365.42$ & $80,372.42$ & 68,071 \\
\hline \multicolumn{2}{|c|}{ Total Industri } & $31,550.79$ & $37,300.34$ & $38,624.63$ & $48,084.08$ & $91,800.67$ & $7,816,689$ \\
\hline \multicolumn{2}{|c|}{ Non Migas } & $34,792.48$ & $40,243.21$ & $42,102.59$ & $52,540.61$ & $98,644.41$ & $84,372.53$ \\
\hline \multicolumn{2}{|c|}{ Gas } & $11,732.05$ & $17,457.68$ & $18,962.87$ & $21,932.82$ & $30,552.90$ & $28,142.35$ \\
\hline
\end{tabular}

\section{IV.2. Hasil Estimasi Model: Panel Multinomial Logit}

Pertumbuhan sektor industri mengalami tren penurunan selama beberapa tahun terakhir. Pada masa sebelum krisis, sektor manufaktur tumbuh rata-rata sebesar $11.8 \%{ }^{5}$ (yoy), sedangkan sesudah krisis pertumbuhan sektor industri turun menjadi $4.6 \%{ }^{6}$ (yoy). Penurunan pertumbuhan tersebut dapat merupakan akibat dari penurunan pertumbuhan output akibat

\begin{tabular}{|c|r|r|r|}
\multicolumn{4}{|c|}{ Tabel II.7 Tingkat Perusahaan yang Masuk, } \\
Keluar, atau Tetap dalam Industri Manufaktur (\%) \\
\hline Year & Stay & Entry & \multicolumn{1}{|c|}{ Exit } \\
1991 & 75,9 & 17,1 & 7,0 \\
1992 & 78,3 & 15,2 & 6,5 \\
1993 & 82,6 & 11,1 & 6,3 \\
1994 & 83,1 & 11,7 & 5,2 \\
1995 & 75,8 & 17,4 & 6,8 \\
1996 & 51,9 & 14,9 & 33,2 \\
1997 & 81,0 & 8,0 & 11,0 \\
1998 & 84,5 & 8,4 & 7,1 \\
1999 & 87,6 & 7,8 & 4,6 \\
2000 & 77,5 & 5,7 & 16,9 \\
2001 & 80,1 & 15,1 & 4,8 \\
2002 & 87,3 & 4,7 & 8,0 \\
2003 & 73,6 & 5,1 & 21,2 \\
2004 & 73,0 & 9,5 & 17,5 \\
2005 & 71,7 & 7,8 & 20,5 \\
2006 & 64,3 & 19,6 & 16,1 \\
\hline
\end{tabular}

5 Rata-rata pertumbuhan industri tahun 1994-1996 6 Rata-rata pertumbuhan industri tahun 2000-2009 
dari kenaikan exit rate pada masa sesudah krisis atau masuknya perusahaan dengan output yang lebih rendah, sementara perusahaan yang keluar dari industri adalah perusahaan dengan output yang tinggi.

Jumlah perusahaan yang masuk, keluar, atau tetap dalam industri secara umum tidak mengalami perubahan dari tahun ke tahun. Rata-rata perusahaan yang bertahan dalam suatu industri adalah $76.8 \%$ setiap tahun, sementara yang masuk adalah 11,2\% per tahun. Jumlah tersebut hampir serupa dengan tingkat perusahaan yang keluar yaitu $12 \%$.

Pada tahun 1996 dan 1997 terjadi peningkatan exit rate yang signifikan yaitu mencapai 33,2\% dan 11,2\%. Hal tersebut menunjukkan bahwa pada masa krisis atau bust dalam perekonomian, perusahaan yang keluar dari industri memiliki jumlah yang besar dan jumlah perusahaan yang masuk mengalami penurunan.

Apabila dibedah ke dalam kode SITC 2 digit, pada masa sebelum krisis sebagian sub industri memiliki kecenderungan yang seimbang antara perusahaan yang masuk dan keluar. Pada masa sebelum krisis, sub industri barang-barang petroleum yang sudah disuling (23) dan barang logam dasar (27) memiliki rata-rata tertinggi perusahaan yang masuk yaitu sebesar 10$11 \%$ per tahun.

Sebaliknya terjadi setelah krisis, hampir seluruh sub industri memiliki jumlah perusahaan yang keluar lebih banyak. Bahkan beberapa sub industri memiliki peningkatan net keluar pada masa sesudah krisis. Sebagai contoh, sub industri tekstil, pada masa sebelum krisis jumlah perusahaan yang keluar dari industri tekstil sekitar 0,2\%, sementara pada masa sesudah krisis jumlah perusahaan yang keluar meningkat menjadi 4,5\% per tahun. Hal yang serupa terjadi pada industri pakaian jadi dan makanan.

Di sisi lain, terdapat beberapa perusahaan yang memiliki pertambahan perusahaan per tahun pada masa sesudah krisis. Sub industri tersebut adalah sub industri peralatan kantor, akuntansi dan komputer (30) serta sub industri produksi motor dan sepeda (34). Dinamika ini sejalan dengan pergerakan sub industri transportasi yang memberikan kontribusi terbesar terhadap total output industri.

Pengolahan panel multinomial logit dilakukan untuk keseluruhan dan sub industri (ISIC 2 digit). Berdasarkan hasil pengolahan, diperoleh faktor-faktor yang mempengaruhi entry/exit rate pada masa boom/bust dalam perekonomian. Faktor-faktor tersebut dibagi menjadi 3 bagian, yaitu : karakteristik perusahaan (ukuran, modal, biaya, produktivitas), karakteristik pasar, kondisi makroekonomi (boom/bust perekonomian). 


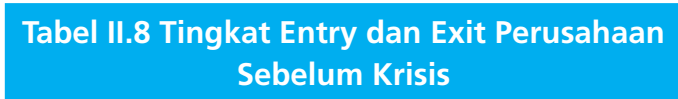

\begin{tabular}{c|c|r|r|r} 
Kode & Stay & \multicolumn{1}{|c|}{ Entry } & \multicolumn{1}{l|}{ Exit } & \multicolumn{1}{l}{ Net } \\
15 & $78.4 \%$ & $10.7 \%$ & $10.9 \%$ & $-0.3 \%$ \\
16 & $77.0 \%$ & $9.2 \%$ & $13.8 \%$ & $-4.6 \%$ \\
17 & $79.8 \%$ & $10.0 \%$ & $10.2 \%$ & $-0.2 \%$ \\
18 & $70.8 \%$ & $14.4 \%$ & $14.8 \%$ & $-0.3 \%$ \\
19 & $75.9 \%$ & $14.1 \%$ & $10.0 \%$ & $4.1 \%$ \\
20 & $67.1 \%$ & $13.9 \%$ & $19.0 \%$ & $-5.1 \%$ \\
21 & $79.5 \%$ & $12.9 \%$ & $7.5 \%$ & $5.4 \%$ \\
22 & $79.2 \%$ & $9.7 \%$ & $11.1 \%$ & $-1.4 \%$ \\
23 & $61.3 \%$ & $25.2 \%$ & $13.4 \%$ & $11.8 \%$ \\
24 & $82.4 \%$ & $8.8 \%$ & $8.8 \%$ & $0.1 \%$ \\
25 & $78.9 \%$ & $12.0 \%$ & $9.1 \%$ & $2.9 \%$ \\
26 & $77.4 \%$ & $12.7 \%$ & $9.9 \%$ & $2.9 \%$ \\
27 & $72.2 \%$ & $18.2 \%$ & $8.9 \%$ & $10.0 \%$ \\
28 & $78.9 \%$ & $12.0 \%$ & $9.1 \%$ & $3.0 \%$ \\
29 & $78.2 \%$ & $13.3 \%$ & $8.5 \%$ & $4.7 \%$ \\
30 & $65.7 \%$ & $20.0 \%$ & $14.3 \%$ & $5.7 \%$ \\
31 & $81.1 \%$ & $10.6 \%$ & $8.3 \%$ & $2.3 \%$ \\
32 & $67.7 \%$ & $20.4 \%$ & $11.9 \%$ & $8.5 \%$ \\
33 & $79.1 \%$ & $10.7 \%$ & $10.2 \%$ & $0.5 \%$ \\
34 & $80.2 \%$ & $9.3 \%$ & $10.4 \%$ & $-1.1 \%$ \\
35 & $75.4 \%$ & $11.1 \%$ & $13.5 \%$ & $-2.4 \%$ \\
36 & $68.7 \%$ & $15.2 \%$ & $16.1 \%$ & $-0.9 \%$ \\
& & & &
\end{tabular}

\begin{tabular}{|c|c|c|c|c|}
\hline Kode & Stay & Entry & Exit & Net \\
\hline 15 & $88,0 \%$ & $3,9 \%$ & $8,1 \%$ & $-4,2 \%$ \\
\hline 16 & $84,2 \%$ & $5,5 \%$ & $10,3 \%$ & $-4,8 \%$ \\
\hline 17 & $89,5 \%$ & $3,0 \%$ & $7,5 \%$ & $-4,5 \%$ \\
\hline 18 & $84,0 \%$ & $4,8 \%$ & $11,3 \%$ & $6,5 \%$ \\
\hline 19 & $88,3 \%$ & $2,0 \%$ & $9,7 \%$ & $-7,7 \%$ \\
\hline 20 & $81,0 \%$ & $4,1 \%$ & $14,9 \%$ & $-10,9 \%$ \\
\hline 21 & $90,5 \%$ & $2,9 \%$ & $6,6 \%$ & $-3,6 \%$ \\
\hline 22 & $90,6 \%$ & $3,4 \%$ & $6,0 \%$ & $2,7 \%$ \\
\hline 23 & $92,1 \%$ & $1,0 \%$ & $0,3 \%$ & $-4,8 \% \%$ \\
\hline 24 & $93,3 \%$ & $2,0 \%$ & $4,7 \%$ & $-2,7 \%$ \\
\hline 25 & $84,6 \%$ & $7,2 \%$ & $8,2 \%$ & $-1,1 \%$ \\
\hline 26 & $85,0 \%$ & $3,5 \%$ & $11,5 \%$ & $-8,0 \%$ \\
\hline 27 & $74,2 \%$ & $1,8 \%$ & $24,0 \%$ & $-22,3 \%$ \\
\hline 28 & $89,5 \%$ & $2,5 \%$ & $8,0 \%$ & $-5,4 \%$ \\
\hline 29 & $91,7 \%$ & $1,3 \%$ & $7,0 \%$ & $-5,7 \%$ \\
\hline 30 & $71,4 \%$ & $28,6 \%$ & $0,0 \%$ & $28,6 \%$ \\
\hline 31 & $95,9 \%$ & $1,0 \%$ & $6,1 \%$ & $-5,1 \%$ \\
\hline 32 & $82,5 \%$ & $4,5 \%$ & $13,0 \%$ & $-8,5 \%$ \\
\hline 33 & $90,4 \%$ & $0,0 \%$ & $9,6 \%$ & $-9,6 \%$ \\
\hline 34 & $83,1 \%$ & $9,7 \%$ & $7,2 \%$ & $2,5 \%$ \\
\hline 35 & $83,3 \%$ & $4,1 \%$ & $12,6 \%$ & $8,6 \%$ \\
\hline 36 & $80,0 \%$ & $8,6 \%$ & $11,4 \%$ & $-2,9 \%$ \\
\hline
\end{tabular}

\section{IV.2.1. Modal Perusahaan}

Modal perusahaan merupakan komponen nilai gedung, tanah, kendaraaan, dan perlengkapan. Semakin besar modal perusahaan maka peluang memasuki industri semakin besar. Modal perusahaan merupakan biaya tetap. Untuk memperoleh keuntungan, perusahaan akan memproduksi dalam kapasitas yang besar.

\begin{tabular}{|l|c|c|}
\multicolumn{3}{c}{ Tabel II.10 } \\
\multicolumn{1}{|c|}{ Rata-rata Modal dan Nilai Produksi Industri Tahun 1990-2006 } \\
\hline \multicolumn{1}{|c|}{ I S I C } & Modal & Produksi \\
21 - PAPER AND PAPER PRODUCTS & 1.670 .000 .000 & 77.800 .000 \\
24 - CHEMICALS AND CHEMICAL PRODUCTS & 875.000 .000 & 51.000 .000 \\
16 - TOBACCO PRODUCTS & 785.000 .000 & 39.600 .000 \\
33 - MEDICAL. PRECISION AND OPTICAL & 603.000 .000 & 16.800 .000 \\
17 - TEXTILES & 514.000 .000 & 21.200 .000 \\
22 - PUBLISHING, PRINTING AND REPRODUCTION OF RECORDED & 477.000 .000 & 10.100 .000 \\
\end{tabular}


Hasil estimasi (lampiran) menunjukkan terdapat perbedaan sensitivitas pertambahan modal terhadap peluang perusahaan masuk industri pada masa bust dan boom. Pada masa bust dalam perekonomian, perusahaan memiliki insentif yang kecil untuk memasuki industri. Modal perusahaan yang masuk ke dalam industri lebih kecil daripada perusahaan yang bertahan. Hal tersebut dapat terlihat dari koefisien modal yang negatif hubungannya terhadap probabilitas perusahaan masuk industri. Hal sebaliknya terjadi pada masa boom dalam perekonomian, koefisien modal yang positif menunjukkan bahwa pertambahan modal akan meningkatkan probabilitas perusahaan masuk industri. Selain itu perusahaan yang masuk ke dalam industri pada masa boom juga memiliki modal yang lebih besar dibandingkan dengan perusahaanperusahaan yang bertahan di industri tersebut.

Apabila dilihat sensitivitas perubahan modal setiap sub industri terhadap probabilitas perusahaan masuk perusahaan pada masa boom, sebagian besar sub industri memiliki hubungan yang positif terhadap modal. Sensitivitas yang terbesar pada sub industri produk non metal (26). Di sisi lain, sub industri dengan modal yang besar juga memiliki sensitivitas positif terhadap perubahan modal. Hal tersebut memberikan alasan mengapa pada masa boom terjadi peningkatan nilai produksi perusahaan manufaktur.

Hal sebaliknya terjadi pada masa bust, besarnya modal perusahaan sebagian besar tidak mempengaruhi peluang memasuki industri. Bahkan di beberapa industri terdapat kecenderungan yang negatif untuk memasuki industri. Sensitivitas negatif terbesar dimiliki oleh industri kertas dan produk-produk kertas (21). Koefisien yang negatif juga menunjukkan pada masa bust, perusahaan-perusahaan yang masuk dalam industri tersebut memiliki modal yang relatif lebih kecil dari perusahaan yang bertahan. Hasil empiris ini juga menunjukkan pada masa bust kecilnya pertumbuhan sektor industri disebabkan oleh perusahaan tidak memiliki insentif memasuki industri dan atau perusahaan yang masuk industri memiliki modal yang kecil dan pada akhirnya tingkat produksi yang kecil.

Perilaku perusahaan yang keluar dari pasar menunjukkan perbedaan yang sangat kecil pada masa boom dan bust. Hasil estimasi menunjukkan perilaku yang sejalan dengan hipotesa awal, dimana kenaikan dari modal perusahaan akan mengurangi peluang perusahaan untuk memasuki industri.

Apabila dilihat perilaku perusahaan lebih detil, pada masa bust, sensitivitas pertambahan modal terhadap probabilitas perusahaan keluar dari industri menunjukkan hubungan yang negatif. Peranan modal terhadap peluang keluarnya perusahaan berpengaruh besar untuk sub industri tembakau (16). Industri-industri dengan kategori modal besar juga memiliki sensitivitas yang besar terhadap perubahan modal. Pada masa bust, perubahan modal tidak berpengaruh terhadap keputusan perusahaan untuk keluar atau tetap dalam industri. 
Hasil estimasi juga menunjukkan pada masa boom, pertambahan $1 \%$ modal perusahaan akan meningkatkan peluang perusahaan bertahan dalam industri, dengan magnitude yang sama. Pada masa boom, industri furniture (36) memiliki sensitivitas yang besar terhadap perubahan modal. Selain industri tersebut, industri lainnya juga memiliki sensitivitas yang besar terhadap perubahan modal.

Hasil estimasi ini menunjukkan bahwa kebijakan-kebijakan yang berimplikasi untuk menambah modal perusahaan akan efektif pada masa boom dan bust perekonomian, akan tetapi pengaruh kebijakan tersebut akan lebih besar pada masa boom. Hal itu akan memberikan implikasi pada peningkatan perusahaan yang masuk dan pengurangan perusahaan yang keluar. Terutama kebijakan penambahan modal pada sub industri yang memiliki rata-rata modal yang tinggi. Hal tersebut akan meningkatkan nilai produksi dan pada akhirnya mendorong pertumbuhan sektor manufaktur.

\section{IV.2.2. Ukuran Perusahaan}

Secara umum ukuran perusahaan yang masuk adalah perusahaan dengan ukuran yang kecil, kecuali perusahaan yang berada pada sub industri peralatan kesehatan. Begitupula perusahaan yang keluar dari industri merupakan perusahaan dengan ukuran perusahaan yang relatif kecil, kecuali perusahaan pada sub industri mesin, radio, dan telekomunikasi. Secara total, pada periode boom, pengurangan total ukuran perusahaan terjadi akibat dinamika perusahaan yang masuk dan keluar. Apabila ukuran perusahaan dibandingkan pada periode boom dan bust, tidak ada perbedaan signifikan di kedua periode tersebut.

Begitupula apabila dilihat dari nilai produksi, perusahaan yang masuk ke dalam industri memiliki nilai produksi yang lebih kecil, kecuali sub industri logam dasar serta peralatan telekomunikasi dan kesehatan. Begitupula perilaku perusahaan yang keluar juga memiliki nilai produksi yang lebih kecil, kecuali perusahaan sub industri logam dasar. Pada masa boom dalam perekonomian, nilai produksi perusahaan yang bertahan lebih besar daripada masa bust, akan tetapi dinamika perusahaan yang masuk dan keluar memberikan penurunan terhadap nilai produksi secara total.

Pada hasil pengolahan dengan menggunakan multinomial panel logit juga ditunjukkan dengan koefisien negatif baik pada masa bust dan boom. Perbedaan ini juga menunjukkan, perusahaan-perusahaan yang masuk pada masa bust dan boom perekonomian memiliki ukuran yang relatif lebih kecil daripada perusahaan yang berada dalam industri tersebut sebelumnya. Hasil empiris ini juga menunjukkan bahwa pada masa boom sekalipun jumlah perusahaan yang masuk ke dalam industri lebih besar, tetapi ukuran perusahaannya lebih kecil daripada masa bust. 


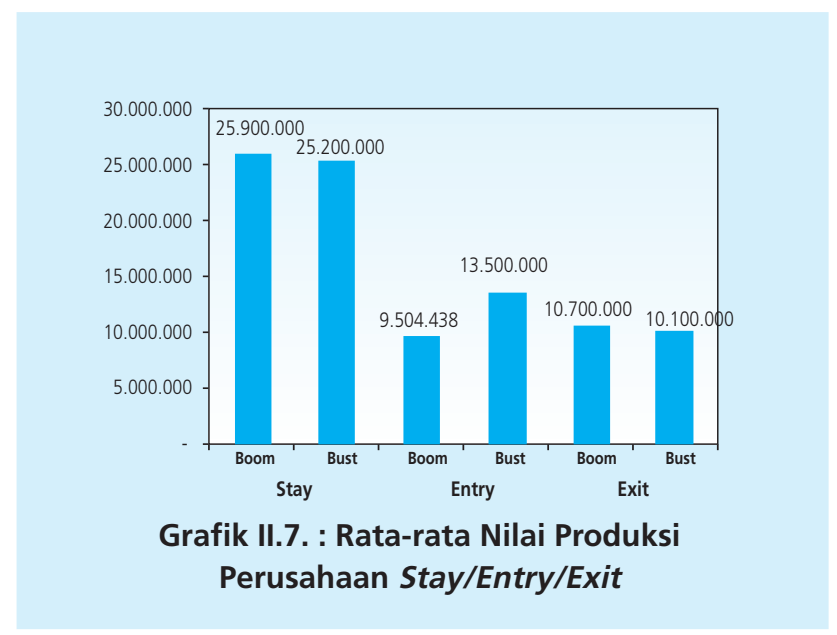

Hal ini dikarenakan ekspektasi pertumbuhan dan profit pada masa bust relatif kecil sehingga perusahaan-perusahaan dengan ukuran kecil tidak mengambil resiko memasuki industri. Pada masa bust, tingkat produksi yang dihasilkan harus besar agar dapat menghasilkan keuntungan yang besar. Dengan jumlah tenaga kerja produksi yang sedikit, akan memberatkan perusahaan mendapatkan nilai produksi yang besar. Sebaliknya pada masa boom, adanya pertumbuhan dan ekspektasi profit akan dapt memberikan keuntungan pada perusahaanperusahaan dengan tenaga kerja yang kecil sekalipun.

Apabila dilihat sensitivitas per industri pada masa boom dan bust, perilaku industri secara total juga terjadi pada sebagian besar sub industri. Pada masa bust, sub industri percetakan (22) yang memasuki industri memiliki jumlah tenaga kerja produksi yang paling kecil. Sementara pada masa boom, perusahaan yang masuk pada sub industri tekstil (17) memiliki ukuran perusahaan yang lebih kecil.

Hal yang menarik yang diperoleh dari hasil estimasi multinomial panel logit, pada beberapa sub industri pengaruh kenaikan jumlah tenaga kerja produksi meningkatkan peluang perusahaan memasuki industri. Pada masa boom, sub industri tersebut adalah industri tembakau (16), industri radio dan telekomunikasi (32) serta karet dan plastik (25). Sementara pada masa bust, penambahan ukuran perusahaan pada sub industri tembakau (16) akan meningkatkan peluang perusahaan yang masuk ke industri tersebut. Hal tersebut sejalan dengan analisis deskriptif yang disampaikan sebelumnya, akhir-akhir ini atau masa boom, sub industri yang banyak menyerap tenaga kerja adalah industri radio dan telekomunikasi.

Ukuran perusahaan yang keluar dari industri juga relatif lebih kecil daripada rata-rata perusahaan yang bertahan. Selain itu perusahaan yang keluar pada masa boom, relatif lebih kecil daripada masa bust. Hal tersebut ditunjukkan dengan tanda/arah negatif koefisien. 
Di sisi lain, koefisien negatif menunjukkan semakin besar jumlah tenaga kerja produksi akan menurunkan probabilitas perusahaan keluar atau dengan kata lain perusahaan akan memilih bertahan dalam industri. Sensitivitas tersebut lebih besar pada masa boom dibandingkan masa bust. Pada masa boom, semakin besar ukuran perusahaan akan mengurangi probabilitas perusahaan keluar lebih besar dibandingkan masa bust. Atau dengan kata lain, perusahaan lebih mudah keluar pada masa bust.

Apabila dilihat sensitivitas ukuran perusahaan terhadap probabilitas perusahaan keluar dari industri secara lebih detil, hampir seluruh perusahaan memiliki perilaku yang sama dengan total industri. Pada masa bust, sensitivitas ukuran perusahaan terhadap peluang perusahaan keluar dari industri terbesar terdapat dalam sub industri tembakau (16). Sementara pada masa boom, sensitivitas ukuran perusahaan terhadap peluang perusahaan yang keluar terbesar terdapat pada sub industri furniture (36).

Perusahaan yang masuk ke dalam maupun yang keluar industri lebih kecil daripada masa bust, sehingga dapat disimpulkan ukuran perusahaan yang bertahan dalam industri dalam masa boom lebih besar pada masa bust. Kebijakan yang dapat meningkatkan ukuran perusahaan melalui peningkatan jumlah tenaga kerja produksi akan memberikan implikasi peningkatan jumlah perusahaan yang bertahan dalam industri.

\section{IV.2.3. Biaya Produksi}

Semakin besar biaya produksi yang didekati dengan upah pekerja produksi akan mengurangi peluang perusahaan yang masuk ke dalam industri. Perilaku tersebut berlaku baik pada masa boom atau bust dalam perekonomian. Pada masa bust perekonomian sensitivitas kenaikan biaya produksi lebih kecil daripada masa boom . Sensitivitas negatif ini juga menunjukkan bahwa perusahaan-perusahan yang masuk memiliki upah produksi yang lebih kecil dibandingkan perusahaan yang tetap dalam industri. Di sisi lain, hasil empiris multinomial panel logit juga menunjukkan bahwa upah produksi perusahaan yang masuk pada masa boom lebih kecil daripada masa bust.

Perilaku yang terjadi pada keseluruhan industri tersebut juga terjadi pada sebagian besar sub industri. Pada masa bust dalam perekonomian, kenaikan biaya produksi akan berpengaruh paling besar pada industri makanan dan minuman (15), sementara pada masa boom industri pakaian jadi(19) memiliki sensitivitas terbesar terhadap biaya produksi.

Di sisi lain, peluang perusahaan keluar dari industri biaya produksi memiliki hubungan positif dengan biaya tenaga kerja produksi. Semakin tinggi biaya tenaga kerja produksi akan 
meningkatkan peluang perusahaan yang keluar pada masa bust perekonomian. Sementara pada masa boom, biaya produksi tidak berpengaruh terhadap keputusan perusahaan keluar dari industri.

Pada masa bust perekonomian, sensitivitas positif biaya produksi terhadap peluang perusahaan keluar dari industri terbesar terdapat pada industri tembakau (16), sementara pada masa boom terdapat pada industri kimia dan produk-produk kimia (24).

Implikasi kebijakan dari analisis ini adalah menekan biaya produksi terutama pada masa bust dalam perekonomian, karena akan mempengaruhi keputusan perusahaan untuk masuk atau keluar perusahaan. Sementara pengurangan biaya produksi pada masa boom, hanya akan mengurangi perusahaan yang masuk ke dalam industri.

\section{IV.2.4. Teknologi Perusahaan}

Pada periode boom, perusahaan yang masuk ke dalam industri dengan tingkat teknologi yang lebih tinggi. Secara total, pada masa boom, teknologi yang masuk ke dalam industri menjadi lebih kecil. Untuk rata-rata perusahaan, pada masa boom dan bust tidak ada perbedaan teknologi yang signifikan.

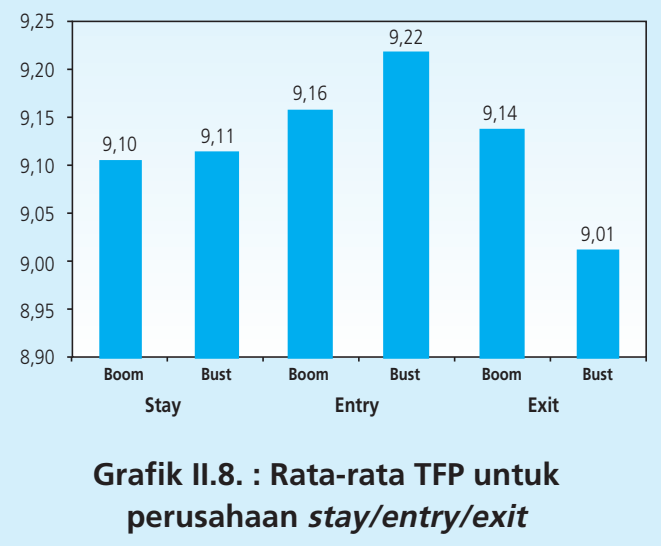

Sebagian besar sub industri manufaktur memiliki ketergantungan yang lebih besar terhadap tenaga kerja dan sebaliknya terhadap modal. Pertambahan 1 unit barang modal memberikan pertambahan yang lebih kecil dibandingkan dengan pertambahan 1 unit tenaga kerja. 
Hasil pengolahan data panel (random effect) untuk setiap industri 2 digit tahun 19902006 menunjukkan sub industri raw materials (yang juga merupakan ekspor utama Indonesia) memiliki ketergantungan besar terhadap tenaga kerja dengan rata-rata koefisien 0,17. Sementara sub industri mesin, telekomunikasi, komputer, memiliki ketergantungan yang lebih besar terhadap barang modal $(0,22)$.

Total koefisien modal dan tenaga kerja juga menunjukan kecenderungan industri manufaktur memiliki pola increasing return to scale, kecuali sub industri minyak olahan. Pertambahan input yang mendorong output terbesar dimiliki oleh sub industri radio, televisi, dan telekomunikasi dan beberapa industri yang cenderung memiliki tingkat teknologi yang tinggi. Oleh karena itu, peningkatan jumlah tenaga kerja di industri berbasis teknologi diperlukan, dengan kombinasi tenaga kerja dan modal yang tinggi, akan menghasilkan output lebih banyak.

Selain peran modal dan tenaga kerja, teknologi juga memiliki kontribusi terhadap output. Sub industri dengan teknologi yang terbesar adalah pengolahan padi, barang dari minyak dan gas bumi, serta alat komunikasi. Sementara sub industri tembakau, tanah liat, dan peralatan fotografi memiliki teknologi yang relatif lebih kecil.

Apabila dibandingkan tahun 1990, tingkat teknologi yang dimiliki industri saat ini mengalami peningkatan. Akan tetapi pertumbuhan teknologi sejak tahun 2000-2006 mengalami perlambatan. Peningkatan teknologi terbesar adalah sub industri serat buatan (rata-rata pertumbuhan ${ }^{7}$ adalah $14.85 \%$ per tahun) sementara pertumbuhan teknologi yang terkecil adalah komponen elektronik (rata-rata pertumbuhan $2.50 \%$ per tahun).

Pada keseluruhan periode waktu (boom/bust), perusahaan yang memasuki industri memiliki tingkat teknologi yang lebih besar dibandingkan perusahaan yang bertahan/keluar dari industri tersebut. Teknologi perusahaan menunjukkan penggunaan teknologi dalam memproduksi output, sehingga teknologi perusahaan yang semakin tinggi akan meningkatkan output. Hasil estimasi panel logit menunjukkan bahwa pada periode bust, perusahaan yang masuk industri memiliki teknologi yang lebih kecil daripada pada masa boom . Hasil estimasi ini sejalan dengan hipotesa awal.

Apabila dilihat perilaku perusahaan secara detail, pada masa bust perusahan yang masuk dengan teknologi terendah adalah industri kayu dan produk-produk kayu (20). Sementara pada masa boom perekonomian, perusahaan yang masuk ke dalam industri memiliki teknologi yang lebih besar. Semakin besar teknologi perusahaan maka peluang perusahaan untuk memasuki industri semakin besar. Sensitivitas terbesar adalah industri makanan dan minuman

7 Rata-rata pertumbuhan industri tahun 2000-2006 
(15), semakin besar teknologi perusahaan di industri tersebut maka peluang perusahaan memasuki industri juga semakin besar.

Sementara pada saat keluar dari industri, perusahaan memiliki kecenderungan teknologi yang lebih tinggi dari industrinya (baik pada masa boom dan bust). Pada masa bust, teknologi perusahaan yang keluar lebih besar daripada masa boom. Apabila dilihat perilaku perusahaan lebih detail, perusahaan yang keluar dari sub industri logam (28) memiliki peluang keluar dari industri yang terbesar dengan kenaikan teknologi, sementara pada masa boom peluang keluar dari industri yang terbesar adalah industri furniture (36).

Hasil perhitungan multinomial panel logit tersebut menunjukkan bahwa pada masa bust perekonomian, dengan kenaikan $1 \%$ teknologi akan menurunkan probabilitas perusahaan yang masuk dan meningkatkan probabilitas perusahaan yang keluar. Sehingga pada masa bust, secara total, perusahaan yang bertahan dalam industri lebih kecil. Sementara pada periode boom, kenaikan 1 \% teknologi menyebabkan peluang perusahaan yang masuk lebih besar daripada yang keluar.

\section{IV.2.5. Karakteristik Pasar}

Tingkat konsentrasi pasar yang menunjukkan besarnya economic of scale juga berbedabeda para setiap industri. Sub industri dengan konsentrasi yang besar memiliki karakteristik perusahaan monopoli, sehingga biaya untuk memasuki industri tersebut relatif besar. Adapun perusahaan yang memiliki konsentrasi pasar yang besar meliputi industri tembakau, plastik, logam, mesin kantor, radio dan komunikasi, serta peralatan kesehatan. Pada sub industri tersebut, secara umum, memiliki entry rate di bawah rata-rata industri.

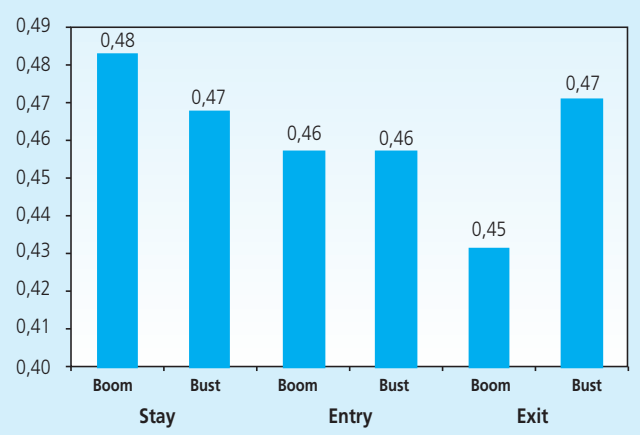

Grafik II.9. : Rata-rata CR Perusahaan Stay/Entry/Exit 
Karakteristik pasar yang cenderung mengarah ke pasar monopoli, menyulitkan perusahaan baru untuk masuk ke dalam pasar tersebut. Hal itu karena biaya untuk mencapai profit maksimum lebih besar dibandingkan dengan pasar yang memiliki karakteristik sempurna, dimana tidak ada halangan untuk masuk/keluar pasar. Hal tersebut dibuktikan dengan hasil empiris yang menunjukkan bahwa baik pada masa boom/bust, karakteristik perusahaan yang mengarah pada monopoli akan mengurangi probabilita perusahaan yang masuk.

Hal sebaliknya terjadi pada karakteristik perusahaan yang keluar dari industri. Perusahaan lebih mudah keluar pada industri yang mengarah pada monopoli, terutama pada masa bust dalam perekonomian. Sementara pada masa boom, karakteristik pasar bukan merupakan faktor yang mempengaruhi keputusan perusahaan untuk tetap atau keluar dari industri.

\section{KESIMPULAN DAN REKOMENDASI KEBIJAKAN}

Berdasarkan hasil analisis kualitatif dan kuantitatif yang telah dilakukan dapat disimpulkan beberapa hal sebagai berikut :

1. Perubahan kondisi ekonomi ditunjukkan dengan perbedaan tingkat perusahaan yang keluar/ masuk. Pada masa krisis ekonomi tahun 1997-1998, terjadi exit rateyang tinggi, sementara perusahaan yang masuk relatif lebih sedikit.

2. Karakteristik perusahaan yang masuk ke dalam industri :

- Pada periode boom, peningkatan peluang perusahaan untuk masuk ke dalam industri sejalan dengan pertambahan modal dan teknologi. Sementara peluang perusahaan untuk masuk pada masa boom berhubungan negatif dengan jumlah tenaga kerja, biaya produksi, serta tingkat konsentrasi pasar.

- Peluang perusahaan untuk memasuki industri selama periode bust akan meningkat dengan penurunan modal dan ukuran, biaya tenaga kerja produksi, teknologi dan konsentrasi pasar.

3. Terdapat beberapa industri yang membutuhkan ukuran yang besar baik dari sisi modal maupun tenaga kerja untuk memasuki industri tersebut, yaitu sub industri radio dan telekomunikasi, serta karet dan plastik.

4. Karakteristik perusahaan yang keluar dari industri :

- Pada periode boom/bust, peluang perusahaan untuk keluar dari industri akan lebih besar apabila biaya tenaga kerja produksi meningkat, ukuran perusahaan menurun, dan modal yang menurun.

Berdasarkan kesimpulan tersebut dapat ditarik beberapa rekomendasi kebijakan. Sensitivitas perusahaan terhadap modal lebih besar pada masa boom dibandingkan masa bust. 
Hal tersebut memberikan konsekuensi, kebijakan untuk meningkatkan modal akan lebih efektif meningkatkan peluang perusahaan masuk industri pada masa boom. Sementara penguatan modal perusahaan pada masa bust akan mencegah perusahaan untuk keluar dari industri. Oleh karena itu, dalam rangka menguatkan industri manufaktur pada masa bust, insentif yang lebih besar dibutuhkan perusahaan untuk memperkuat permodalan.

Hasil pengolahan data juga menunjukkan perusahaan dengan ukuran besar memiliki peluang yang besar untuk bertahan dalam industri, hal tersebut terkait dengan economic of scale. Sementara perusahaan kecil lebih rentan untuk masuk dan keluar pada masa boom/ bust. Pada masa bust dalam perekonomian, biaya tenaga kerja produksi perlu ditekan karena akan mempengaruhi keputusan perusahaan untuk masuk atau keluar perusahaan. Sementara pengurangan biaya produksi pada masa boom, hanya akan mengurangi perusahaan yang masuk ke dalam industri.

Pada periode boom, peluang perusahaan untuk memasuki industri lebih besar untuk perusahaan dengan teknologi yang besar. Sementara pada masa bust, peluang perusahaan untuk memasuki industri lebih besar dengan teknologi rendah, ukuran yang kecil dan tingkat konsentrasi pasar yang rendah. Oleh karena itu, industri dengan skala kecil dan teknologi yang rendah memiliki peran yang penting untuk counter cycling perekonomian pada masa bust. 


\section{DAFTAR PUSTAKA}

Ahn, Sanghoon, (2001). "Firm Dynamics and Productivity Growth : A Review of Micro Evidence From OECD Countries", OECD Economics Department, Working Paper No. 97.

Austin, John S dan David I. Rosenbaum. "The Determinants of Entry and Exit Rates Into US Manufacturing Industries", Review of Industrial Organization, Vol.5 No. 2.

Bernard, Andrew B. and J.B. Jensen. (2004). "Why Some Firms Export," The Review of Economics and Statistics, Vol. 86, No. 2.

Caballero, R. J. dan M. L. Hammour, (1994). "The Cleansing Effect of Recessions," American Economic Review, No.84, 1350-1368.

Caballero, R. J. dan M. L. Hammour, (2005). "The Cost of Recessions Revisited: A ReverseLiquidationist View," American Economic Review, No.84, 1350-1368.

Davis, S.J. dan J.C. Haltawanger, (1990)." "Gross Job Creation and Destruction: Microeconomic

Evidence and Macroeconomic Implications," NBER Macroeconomic Annual V, 123-168.

Holzl Werner dan Leopold Sogner, (2004). "Entry and Exit Dynamics in The Austrian

Manufacturing Industries." Vienna University of Economics and Business Administration, Working Paper No. 36.

Ilmakunnas, Pekka dan Jukka Topi (1999). "Microeconomic and Macroeconomic Influences on Entry

and Exit of Firms." Review of Industrial Organization No. 15, 283-301.

Lee, Y. and T. Mukoyama, (2008). "Entry, Exit and Plant-Level Dynamics over the Business

Cycle," Federal Reserve Bank of Cleveland Working Paper 07-18R.

Martin-Marcos, Ana dan Jordi Jaumandreu, (2004). "Entry, Exit, and Productivity Growth: Spanish Manufacturing during The Eighties." Spanish Economic Review No. 6, 211-226.

McQueen, Grant and Thorley, Steven, (1993). "Asymmetric business cycle turning points." Journal of Monetary Economics, 31, 341-362.

Yang, Qing Gong, (2004). "Entry, Exit and The Dynamics of Productivity Growth in Chinese Manufacturing Industry", ESRC Centre for Business Research, University of Cambridge, Working Paper No. 284. 


\section{LAMPIRAN}

\section{Efek Marjinal - Entry Bust}

\begin{tabular}{|c|c|c|c|c|c|c|c|c|c|c|c|c|}
\hline ISIC & \multicolumn{2}{|c|}{ Ukuran } & \multicolumn{2}{|c|}{ Modal } & \multicolumn{2}{|c|}{ Upah } & \multicolumn{2}{|c|}{ Konsentrasi Pasar } & \multicolumn{2}{|c|}{ Teknologi } & \multicolumn{2}{|c|}{ Konstanta } \\
\hline 15 & NS & & $(0.002)$ & $* * *$ & $(0.036)$ & $\star * *$ & $(0.048)$ & $* \star *$ & $(0.027)$ & $\star * \star$ & 0.199 & $\star * *$ \\
\hline 16 & 0.052 & $\star * *$ & $(0.003)$ & ** & $(0.060)$ & $* * *$ & $(0.163)$ & $* * *$ & 0.006 & $\star *$ & 0.090 & $* * *$ \\
\hline 17 & NS & & NS & & $(0.025)$ & $* * *$ & 0.105 & $\star * *$ & $(0.027)$ & $* * *$ & 0.104 & $\star \star *$ \\
\hline 18 & NS & & NS & & $(0.002)$ & $* * *$ & $(0.017)$ & $* * *$ & 0.002 & ** & $(0.070)$ & $* \star *$ \\
\hline 19 & $(0.035)$ & $* \star *$ & $(0.002)$ & ** & 0.030 & $* * *$ & $(0.070)$ & ** & $(0.075)$ & $\star * *$ & 0.142 & $* * *$ \\
\hline 20 & $(0.030)$ & $* * *$ & NS & & $(0.023)$ & $* * *$ & $(0.159)$ & $\star * *$ & $(0.109)$ & $* * *$ & 0.583 & $* * *$ \\
\hline 21 & $(0.074)$ & $\star * *$ & $(0.006)$ & $* * *$ & 0.044 & $* * *$ & NS & & $(0.124)$ & $\star * *$ & 0.260 & $* * *$ \\
\hline 22 & $(0.114)$ & $* * *$ & NS & & NS & & 0.276 & $\star \star *$ & $(0.073)$ & $\star \star *$ & 0.508 & $* * *$ \\
\hline 23 & NS & & NS & & NS & & NS & & NS & & NS & \\
\hline 24 & $(0.102)$ & $\star * *$ & NS & & 0.028 & $\star *$ & 0.214 & $\star \star \star$ & $(0.096)$ & $* * *$ & 0.418 & $* * *$ \\
\hline 25 & $(0.030)$ & $* * *$ & $(0.003)$ & $* * *$ & 0.025 & $* * *$ & $(0.268)$ & $\star * *$ & $(0.071)$ & $* * *$ & 0.179 & $* * *$ \\
\hline 26 & $(0.030)$ & $\star * *$ & NS & & $(0.015)$ & $* * *$ & $(0.120)$ & $\star * *$ & NS & & $(0.049)$ & $\star * *$ \\
\hline 27 & $(0.034)$ & $* * *$ & 0.003 & ** & NS & & NS & & $(0.021)$ & $* * *$ & 0.029 & $\star *$ \\
\hline 28 & $(0.001)$ & $* * *$ & NS & & 0.000 & $* * *$ & $(0.003)$ & $\star * *$ & $(0.000)$ & $* * *$ & $(0.003)$ & $\star * *$ \\
\hline 29 & $(0.077)$ & $* * *$ & NS & & 0.041 & $* *$ & 0.412 & $\star * *$ & $(0.094)$ & $\star * *$ & 0.203 & $\star * *$ \\
\hline 31 & 0.007 & $* * *$ & NS & & $(0.008)$ & $* * *$ & 0.010 & $\star * *$ & $0.008)$ & $\star \star \star$ & 0.071 & $* * *$ \\
\hline 32 & $(0.000)$ & * & $(0.000)$ & $* * *$ & 0.000 & $* * *$ & $(0.000)$ & $* * *$ & NS & & $(0.000)$ & $* * *$ \\
\hline 33 & NS & & NS & & NS & & $(0.065)$ & * & $(0.004)$ & $* * *$ & $(0.052)$ & $\star * *$ \\
\hline 34 & $(0.056)$ & ** & NS & & 0.026 & * & NS & & $(0.069)$ & $\star * *$ & 0.139 & $* *$ \\
\hline 35 & NS & & $(0.001)$ & ** & NS & & $(0.176)$ & $\star * *$ & $(0.010)$ & $* * *$ & $(0.049)$ & $\star * *$ \\
\hline 36 & $(0.022)$ & $* * *$ & NS & & NS & & $(0.058)$ & $\star * *$ & NS & & $(0.058)$ & $\star * *$ \\
\hline Total & $(0.014)$ & $* * *$ & $(0.002)$ & $* * *$ & $(0.020)$ & $* * *$ & $(0.011)$ & $* * *$ & $(0.022)$ & ** & $(0.005)$ & $* * *$ \\
\hline
\end{tabular}

\section{Efek Marjinal - Exit Bust}

\begin{tabular}{|c|c|c|c|c|c|c|}
\hline ISIC & Ukuran & Modal & Upah & Konsentrasi Pasar & Teknologi & Konstanta \\
\hline 15 & $(0.000) * * *$ & $(0.000) * * *$ & $0.000 * * *$ & $(0.000)^{* * *}$ & $0.000 * * *$ & $(0.000)^{* * *}$ \\
\hline 16 & $(0.014) * * *$ & $(0.001)^{* * *}$ & $0.005 * * *$ & $0.039 * *$ & $0.003 * * *$ & $(0.023)^{* * *}$ \\
\hline 17 & $(0.000) * * *$ & NS & NS & $(0.000)^{* * *}$ & $0.000 * * *$ & $(0.000)^{* * *}$ \\
\hline 18 & $(0.000) * * *$ & $(0.000)^{* * *}$ & NS & $0.000 * * *$ & $0.000 * * *$ & $(0.002)^{* * *}$ \\
\hline 19 & $(0.000) * *$ & $(0.000)^{* * *}$ & NS & $0.001 * * *$ & $0.000 * * *$ & $(0.001)^{* * *}$ \\
\hline 20 & $(0.000) * * *$ & $(0.000)^{* * *}$ & NS & $0.000 *$ & $0.000 * * *$ & $(0.000)^{* * *}$ \\
\hline 21 & $(0.000) * *$ & NS & $0.000 *$ & $0.000^{*}$ & $0.000 * *$ & $(0.000)^{* * *}$ \\
\hline 22 & $(0.000) * * *$ & $(0.000)^{\star *}$ & $0.000 * * *$ & $0.000 * *$ & $0.000 * * *$ & $(0.000)^{* * *}$ \\
\hline 23 & NS & NS & NS & NS & NS & $(0.003)^{* * *}$ \\
\hline 24 & $(0.000) * * *$ & NS & NS & $0.000 * * *$ & $0.000 * * *$ & NS \\
\hline 25 & NS & $(0.000)^{* *}$ & $(0.000)^{*}$ & $(0.001)^{\star *}$ & $0.001 * * *$ & $(0.010)^{* * *}$ \\
\hline 26 & $(0.003) * * *$ & NS & NS & $(0.003)^{*}$ & $0.002 * * *$ & $(0.029)^{* * *}$ \\
\hline 27 & 0.039 * & NS & $(0.043)^{* * *}$ & $(0.682)^{\star * *}$ & $0.044^{* * *}$ & $(0.722)^{* * *}$ \\
\hline 28 & $(0.000) * * *$ & $(0.000) * * *$ & NS & NS & $0.000 * * *$ & $(0.000)^{* * *}$ \\
\hline 29 & NS & NS & NS & NS & $0.000 * * *$ & $(0.002)^{* * *}$ \\
\hline 31 & $(0.000) * * *$ & $(0.000)^{*}$ & $0.000 * *$ & NS & $0.000 * * *$ & $(0.000)^{\star * *}$ \\
\hline 32 & NS & NS & NS & $(0.003)^{*}$ & $0.001 * * *$ & $(0.020)^{* * *}$ \\
\hline 33 & NS & NS & NS & NS & $0.000 * *$ & $(0.002)^{\star * *}$ \\
\hline 34 & $(0.001) * * *$ & NS & NS & NS & NS & $(0.006)^{* * *}$ \\
\hline 35 & $(0.001) * * *$ & $(0.000)^{* * *}$ & $0.000 * *$ & NS & NS & $(0.006)^{\star * *}$ \\
\hline 36 & $(0.000) * * *$ & NS & NS & $0.000 * *$ & $0.000 * * *$ & $(0.001)^{* * *}$ \\
\hline Total & $(0.001) * * *$ & $(0.000)^{* * *}$ & $0.000 * * *$ & $0.000^{* * *}$ & $0.001 * * *$ & $(0.007)^{\star * *}$ \\
\hline
\end{tabular}




\section{Efek Marjinal - Entry Boom}

\begin{tabular}{|c|c|c|c|c|c|c|c|c|c|c|c|c|}
\hline ISIC & \multicolumn{2}{|c|}{ Ukuran } & \multicolumn{2}{|c|}{ Modal } & \multicolumn{2}{|c|}{ Upah } & \multicolumn{2}{|c|}{ Konsentrasi Pasar } & \multicolumn{2}{|c|}{ Teknologi } & \multicolumn{2}{|c|}{ Konstanta } \\
\hline 15 & $(0.063)$ & $* * *$ & NS & & $(0.081)$ & $* * *$ & $(0.055)$ & ** & 0.104 * & *** & $(0.227)$ & $* * *$ \\
\hline 16 & 0.000 & $\star * *$ & 0000 & * & $(0.000)$ & ** & NS & & $0.000 *$ & $\star * *$ & 0.000 & $\star *$ \\
\hline 17 & $(0.107)$ & $\star * *$ & 0.009 & $\star * *$ & $(0.081)$ & $* \star *$ & $(0.052)$ & & $0.086 *$ & $\star \star *$ & NS & \\
\hline 18 & $(0.020)$ & * & 0.004 & $* * *$ & $(0.073)$ & $* * *$ & $(0.100)$ & $\star * *$ & $0.083 *$ & $\star * *$ & $(0.192)$ & ** \\
\hline 19 & NS & & NS & & $(0.088)$ & $* * *$ & NS & & $0.088 *$ & $\star * *$ & NS & \\
\hline 20 & $(0.014)$ & $\star * *$ & NS & & $(0.015)$ & $* * *$ & $(0.040)$ & $* * *$ & $0.022 *$ & $\star * *$ & $(0.084)$ & $* * *$ \\
\hline 21 & $(0.104)$ & ** & NS & & NS & & $(2.526)$ & $* * *$ & NS & & (1.083) & $\star * *$ \\
\hline 22 & $(0.021)$ & $\star *$ & NS & & $(0.019)$ & $* * *$ & NS & & $0.024 *$ & $\star * *$ & $(0.090)$ & * \\
\hline 23 & NS & & 0.000 & $\star *$ & NS & & NS & & 0.000 * & * & $(0.004)$ & * \\
\hline 24 & $(0.016)$ & $* *$ & 0.004 & $* * *$ & $(0.042)$ & $* * *$ & NS & & $0.014 *$ & $* * *$ & 0.210 & $\star * *$ \\
\hline 25 & 0.019 & $\star * *$ & 0.001 & $\star * *$ & $(0.031)$ & $* * *$ & NS & & $0.024 *$ & $\star * *$ & NS & \\
\hline 26 & $(0.092)$ & $\star \star *$ & 0.010 & $\star * *$ & $(0.037)$ & $* * *$ & $(0.201)$ & $* * *$ & $0.038 *$ & $\star * *$ & NS & \\
\hline 27 & $(0.050)$ & * & NS & & NS & & NS & & NS & & 0.337 & $\star *$ \\
\hline 28 & $(0.023)$ & ** & 0.003 & $* * *$ & $(0.047)$ & $* * *$ & NS & & 0.027 * & $\star * \star$ & 0.194 & $\star * *$ \\
\hline 29 & NS & & 0.007 & $\star * *$ & $(0.052)$ & $* * *$ & NS & & $0.023 *$ & $\star * *$ & NS & \\
\hline 31 & NS & & 0.001 & * & $(0.023)$ & $* * *$ & 0.063 & $* * *$ & NS & & 0.173 & $* * *$ \\
\hline 32 & 0.192 & $* * *$ & 0.008 & ** & $(0.063)$ & $* * *$ & $(0.526)$ & $* * *$ & $0.049 *$ & $\star * *$ & NS & \\
\hline 33 & NS & & 0.000 & * & NS & & NS & & NS & & $(0.018)$ & ** \\
\hline 34 & NS & & NS & & $(0.053)$ & * & 0.349 & $* * *$ & 0.036 * & $* * *$ & NS & \\
\hline 35 & $(0.004)$ & $* * *$ & NS & & NS & & NS & & 0.002 * & $\star * *$ & $(0.029)$ & $* * *$ \\
\hline 36 & 0.000 & $\star * *$ & 0.002 & $\star * *$ & $(0.006)$ & $* * *$ & $(0.063)$ & $* *$ & $0.014 *$ & $\star * *$ & NS & \\
\hline Total & $(0.077)$ & $\star * *$ & 0.006 & $* * *$ & $(0.078)$ & $* * *$ & $(0.027)$ & $* * *$ & $0.074 *$ & $* * *$ & 0.118 & $* * *$ \\
\hline
\end{tabular}

\section{Efek Marjinal - Exit Boom}

\begin{tabular}{|c|c|c|c|c|c|c|}
\hline ISIC & Ukuran & Modal & Upah & Konsentrasi Pasar & Teknologi & Konstanta \\
\hline 15 & $(0.007)^{\star \star *}$ & $(0.000)^{* * *}$ & NS & $0.006 * * *$ & $0.001 * * *$ & $(0.003)^{*}$ \\
\hline 16 & $(0.000)^{* * *}$ & NS & NS & $(0.009)^{\star * *}$ & $(0.000)^{* * *}$ & $(0.001)^{* * *}$ \\
\hline 17 & $(0.011)^{\star * \star}$ & $(0.001)^{\star * *}$ & $0.000 * *$ & $0.007^{\star}$ & $0.004^{* * *}$ & NS \\
\hline 18 & $(0.002)^{\star \star \star}$ & $(0.000)^{* * *}$ & $0.001 *$ & NS & $0.001 * * *$ & $(0.006)^{\star * *}$ \\
\hline 19 & $(0.011)^{* * *}$ & $(0.001)^{* *}$ & NS & $0.055^{* * *}$ & $0.005^{* * *}$ & NS \\
\hline 20 & $(0.018)^{\star \star}$ & $(0.002)^{* * *}$ & NS & NS & $0.020 * * *$ & $(0.108)^{\star *}$ \\
\hline 21 & $(0.001)^{\star \star *}$ & $(0.000)^{* *}$ & NS & $0.023 * * *$ & $0.001 * * *$ & $0.007 * *$ \\
\hline 22 & $(0.004)^{* * *}$ & $(0.000)^{* * *}$ & NS & $(0.009)^{*}$ & $0.001 * * *$ & $(0.015)^{\star * *}$ \\
\hline 23 & $(0.001)^{*}$ & NS & NS & NS & NS & NS \\
\hline 24 & $(0.005)^{\star * \star}$ & $(0.001)^{*}$ & $0.002 * * *$ & NS & $0.002 * * *$ & NS \\
\hline 25 & $(0.002)^{\star *}$ & $(0.000)^{* * *}$ & NS & $(0.002)^{\star *}$ & $(0.001)^{\star * *}$ & $(0.006)^{* *}$ \\
\hline 26 & $(0.009)^{\star * \star}$ & NS & $0.001 *$ & $(0.002)^{\star}$ & $0.001 * * *$ & $(0.008)^{\star}$ \\
\hline 27 & $(0.000)^{* * *}$ & NS & NS & NS & $0.000 * *$ & $(0.000)^{*}$ \\
\hline 28 & $(0.000)^{\star * *}$ & $(0.000)^{*}$ & NS & NS & $(0.000)^{* * *}$ & $(0.002)^{\star *}$ \\
\hline 29 & $(0.003)^{\star * *}$ & NS & NS & NS & $0.001 * * *$ & $(0.016)^{\star}$ \\
\hline 31 & $(0.000)^{* * *}$ & $(0.000)^{*}$ & $0.000 * *$ & NS & $0.000 * * *$ & $(0.000)^{* * *}$ \\
\hline 32 & NS & $(0.001)^{*}$ & NS & $(0.077)^{\star * *}$ & NS & $(1.000)^{*}$ \\
\hline 33 & NS & NS & NS & NS & NS & $(0.001)^{* * *}$ \\
\hline 34 & $(0.007)^{\star \star}$ & $(0.001)^{*}$ & NS & $(0.011)$ & $(0.000)^{\star *}$ & NS \\
\hline 35 & $(0.011)^{* * *}$ & NS & NS & $(0.039)^{\star *}$ & $0.002^{* * *}$ & $(0.038)^{\star *}$ \\
\hline 36 & $(0.135)^{* * *}$ & $(0.010)^{* * *}$ & $(0.061)^{* * *}$ & NS & $0.068^{* * *}$ & $0.550^{* * *}$ \\
\hline Total & $(0.008)^{\star * *}$ & $(0.000)^{* * *}$ & NS & NS & $0.001 * * *$ & $(0.018)^{\star \star *}$ \\
\hline
\end{tabular}




\section{Keterangan Kode Kelompok Industri ${ }^{8}$}

\begin{tabular}{l|l} 
Kode ISIC & \multicolumn{1}{c}{ Keterangan } \\
15 & MANUFACTURE OF FOOD PRODUCTS AND BEVERAGES \\
16 & MANUFACTURE OF TOBACCO PRODUCTS \\
17 & MANUFACTURE OF TEXTILES \\
18 & MANUFACTURE OF WEARING APPAREL; DRESSING AND DYEING \\
19 & TANNING AND DRESSING OF LEATHER; MANUFACTURE OF \\
20 & MANUFACTURE OF WOOD AND OF PRODUCTS OF WOOD AND \\
21 & MANUFACTURE OF PAPER AND PAPER PRODUCTS \\
22 & PUBLISHING, PRINTING AND REPRODUCTION OF RECORDED \\
23 & MANUFACTURE OF COKE, REFINED PETROLEUM PRODUCTS \\
24 & MANUFACTURE OF CHEMICALS AND CHEMICAL PRODUCTS \\
25 & MANUFACTURE OF RUBBER AND PLASTICS PRODUCTS \\
26 & MANUFACTURE OF OTHER NON-METALLIC MINERAL PRODUCTS \\
27 & MANUFACTURE OF BASIC METALS \\
28 & MANUFACTURE OF FABRICATED METAL PRODUCTS \\
29 & MANUFACTURE OF MACHINERY AND EQUIPMENT N.E.C. \\
30 & MANUFACTURE OF OFFICE, ACCOUNTING AND COMPUTING \\
31 & MANUFACTURE OF ELECTRICAL MACHINERY AND APPARATUS \\
32 & MANUFACTURE OF RADIO, TELEVISION AND COMMUNICATION \\
33 & MANUFACTURE OF MEDICAL, PRECISION AND OPTICAL \\
34 & MANUFACTURE OF MOTOR VEHICLES, TRAILERS \\
35 & MANUFACTURE OF OTHER TRANSPORT EQUIPMENT \\
36 & MANUFACTURE OF FURNITURE; MANUFACTURE N.E.C. \\
&
\end{tabular}

\section{Periodisasi Boom Bust Perekonomian (Upah Riil)}

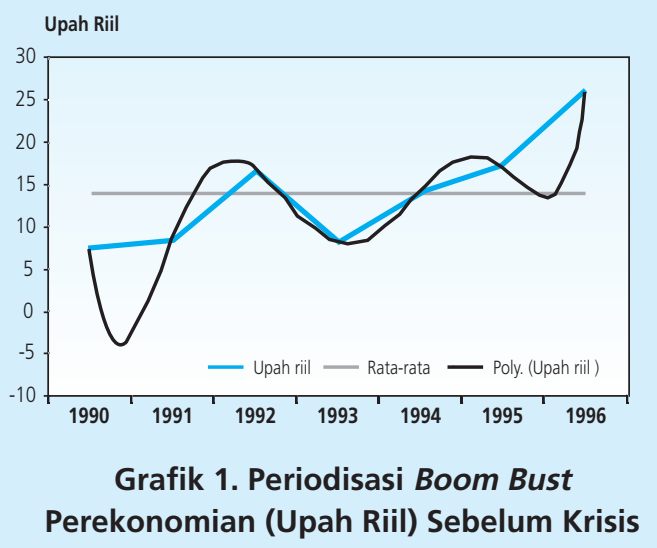

8 Cabang industri non migas : industri makanan, minuman, tembakau, alat angkut, mesin dan peralatannya, pupuk, kimia, barang dari karet, tekstil, barang kulit, dan alas kaki. 


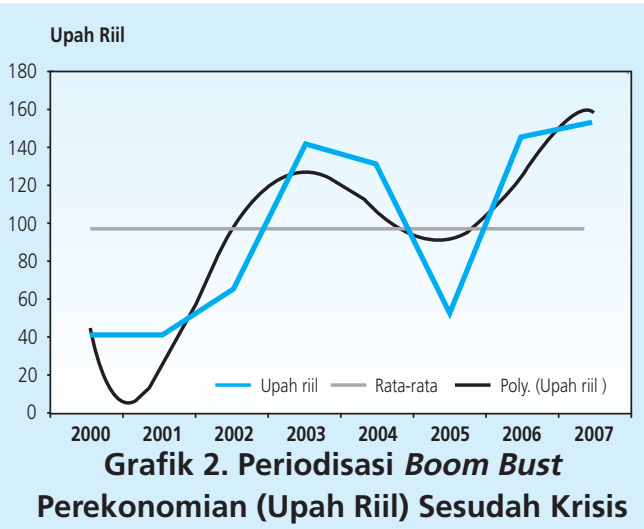

\section{Heustman Test Panel Solow Residual}

\begin{tabular}{|l|ll|}
\hline Ho & $:$ & difference in coefficients not systematic (fixed effect) \\
\hline $\mathrm{Hi}$ & $:$ & difference in coefficients systematic (random effect) \\
\hline chi2(2) & $=$ & $(\text { b-B })^{\prime}\left[\left(V_{-} b-V \_B\right)^{\wedge}(-1)\right](b-B)$ \\
& $=90.9$ \\
\hline Prob>chi2 & $=0.0000$ \\
\hline
\end{tabular}

Hasil Hausman Test menunjukkan pengolahan data untuk memperoleh residual digunakan metode random.

\section{Uji Signifikansi Solow Residual}

Tabel 1. Uji Signifikansi Solow Residual

\begin{tabular}{|c|c|c|}
\hline ISIC & Koef L & Koef K \\
\hline 15 & $0.91 * *$ & $0.22 * * *$ \\
\hline 16 & 1.19 & $0.18 * * *$ \\
\hline 17 & $1.12 * * *$ & $0.16 * * *$ \\
\hline 18 & 0.99 & 0.15 \\
\hline 19 & $0.96 * * *$ & $0.16^{* * *}$ \\
\hline 20 & 1.06 ** & $0.13^{* * *}$ \\
\hline 21 & 1.18 & $0.14 * * *$ \\
\hline 22 & $1.09 * *$ & $0.16 * * *$ \\
\hline 23 & 0.81 & $0.14^{* * *}$ \\
\hline 24 & $1.14^{* *}$ & $0.16^{* * *}$ \\
\hline 25 & 0.96 ** & $0.15^{\star \star *}$ \\
\hline 26 & $1.13 * * \star$ & $0.17 * * *$ \\
\hline 27 & 0.98 & $0.22 * * *$ \\
\hline 28 & 1.02 & $0.19 * * *$ \\
\hline 29 & 1.03 & $0.24^{* * *}$ \\
\hline 30 & 0.81 & $0.27^{* * *}$ \\
\hline 31 & 0.96 & $0.24^{\star * *}$ \\
\hline 32 & $1.14 * * *$ & $0.27 * * *$ \\
\hline 34 & $1.14 * * *$ & $0.2 * * *$ \\
\hline 35 & 1.05 & $0.24^{\star * *}$ \\
\hline 36 & $0.89 * * *$ & $0.13 * * *$ \\
\hline 37 & $0.86 * * *$ & 0.2 \\
\hline
\end{tabular}




\section{Distribusi Perusahaan Berdasarkan Teknologi yang digunakan}

Tabel 2. Distribusi Perusahaan Tahun 2006

Berdasarkan Teknologi

\begin{tabular}{|c|r|r|r|}
\hline ISIC & Kecil & Sedang & Besar \\
15 & $0 \%$ & $81 \%$ & $19 \%$ \\
16 & $100 \%$ & $0 \%$ & $0 \%$ \\
17 & $0 \%$ & $100 \%$ & $0 \%$ \\
18 & $2 \%$ & $98 \%$ & $0 \%$ \\
19 & $0 \%$ & $100 \%$ & $0 \%$ \\
20 & $66 \%$ & $34 \%$ & $0 \%$ \\
21 & $0 \%$ & $100 \%$ & $0 \%$ \\
22 & $0 \%$ & $70 \%$ & $30 \%$ \\
23 & $0 \%$ & $0 \%$ & $100 \%$ \\
24 & $0 \%$ & $0 \%$ & $100 \%$ \\
25 & $0 \%$ & $29 \%$ & $71 \%$ \\
26 & $49 \%$ & $38 \%$ & $12 \%$ \\
27 & $0 \%$ & $0 \%$ & $100 \%$ \\
28 & $0 \%$ & $0 \%$ & $100 \%$ \\
29 & $0 \%$ & $42 \%$ & $58 \%$ \\
30 & $0 \%$ & $0 \%$ & $100 \%$ \\
31 & $0 \%$ & $24 \%$ & $76 \%$ \\
32 & $0 \%$ & $0 \%$ & $100 \%$ \\
33 & $53 \%$ & $36 \%$ & $10 \%$ \\
34 & $0 \%$ & $28 \%$ & $72 \%$ \\
35 & $1 \%$ & $41 \%$ & $57 \%$ \\
36 & $0 \%$ & $100 \%$ & $0 \%$ \\
37 & $9 \%$ & $61 \%$ & $0 \%$ \\
Total & $14 \%$ & & $23 \%$ \\
& & & \\
\hline & & & \\
\hline
\end{tabular}

